\title{
Plevral hastalıkların
} görüntülenmesi: Akciğer grafisi temelinde görüntüleme yöntemlerinin değerlendirilmesi

\author{
Necdet POYRAZ ${ }^{1}$ \\ Havva KALKAN ${ }^{2}$ \\ Kemal ÖDEV ${ }^{1}$ \\ Sami CERAN ${ }^{3}$
}

\footnotetext{
${ }^{1}$ Necmettin Erbakan Üniversitesi Meram Tıp Fakültesi, Radyoloji Anabilim Dalı, Konya, Türkiye

${ }^{1}$ Department of Radiology, Faculty of Meram Medicine, Necmettin Erbakan University, Konya, Turkey

2 Ağrı Devlet Hastanesi, Radyoloji Kliniği, Ağrı, Türkiye

${ }^{2}$ Clinic of Radiology, Ağrı State Hospital, Agri, Turkey

${ }^{3}$ Necmettin Erbakan Üniversitesi Meram Tıp Fakültesi, Göğüs Cerrahisi Anabilim Dalı, Konya, Türkiye

${ }^{3}$ Department of Chest Surgery, Faculty of Meram Medicine, Necmettin Erbakan University, Konya, Turkey
}

\section{ÖZET}

Plevral hastalıkların görüntülenmesi: Akciğer grafisi temelinde görüntüleme yöntemlerinin değerlendirilmesi

Plevra kaynaklı patolojilerin değerlendirilmesinde kullanılan birincil tanı yöntemi konvansiyonel akciğer radyografisidir. Sıklıkla görülen plevra patolojisi plevral kalınlaşma ve efüzyondur. Arka ön akciğer radyografisi (PA, posteroanterior) küçük miktardaki plevral efüzyonu göstermeyebilir. Lateral dekübitus radyografisi ve toraks ultrasonografisi (USG) az miktardaki plevral efüzyonu ortaya koymada daha etkin yöntemlerdir. PA radyografide tek taraflı homojen yoğunluk artışı gösteren olgularda toraks ultrasonografisi plevral ve parankimal patolojilerin ayırıcı tanısında yararlı bilgiler vermektedir. Akciğer radyografisinde saptanan plevral efüzyon veya kalınlaşma altta yatan hastalığı veya parankimal patolojiyi gizleyebilir. Bu nedenle bilgisayarlı tomografi (BT) plevral hastalığın yaygınlığını ve nedenini ortaya koymada yararlı bilgiler sağlamaktadır. BT(koronal ve sagital reformat görüntüler) plevral kalınlaşma veya efüzyonla birlikte bulunan parankimal lezyonların ayırt edilmesini sağlayabilir. Ayrıca BT gögüs duvarı, mediasten ve diyafragma invazyonunu, hiler ve/veya mediastinal lezyonları ayrıntılı olarak gösterebilir. Manyetik rezonans görüntüleme (MRG) standart noninvaziv yöntemlerin yetersiz kaldığı olgularda tamamlayıcı yöntem olarak kullanılabilir.

Anahtar kelimeler: Plevra hastalıkları, radyografi, ultrasonografi, bilgisayarlı tomografi

\section{SUMMARY}

\section{Imaging of pleural diseases: evaluation of imaging methods based on chest radiography}

The most commonly employed radiologic method in diagnosis of pleural diseases is conventional chest radiograph. The commonest chest$X$-Ray findings are the presence of pleural effusion and thickening. Small pleural effusions are not readily identified on posteroanterior chest radiograph. However, lateral decubitus chest radiograph and chest ultrasonography may show small pleural effusions. These are more efficient methods than posteroanterior chest radiograph in the erect position for demonstrating small amounts of free pleural effusions. Chest ultrasonograph may be able to help in distinguishing the pleural pathologies from parenchymal lesions. On chest radiograph pleural effusions or pleural thickening may obscure the visibility of the underlying disease or parenchymal abnormality. Thus, computed tomography (CT) may provide additional information of determining the extent and severity of pleural disease and may help to differentiate malign pleural lesions from the benign ones. Moreover, CT may provide the differentiation of parenchmal abnormalities from pleural pathologies. $C T$ (coronal and sagittal reformatted images) that also show invasion of chest wall, mediastinum and diaphragm, as well as enlarged hilar or mediastinal lymph nodes. Standart non-invasive imaging techniques may be supplemented with magnetic resonans imaging (MRI).

Key words: Pleural diseases, radiography, ultrasonography, computed tomography

\section{Yazışma Adresi (Address for Correspondence)}

Dr. Necdet POYRAZ

Necmettin Erbakan Üniversitesi Meram Tıp Fakültesi, Radyoloji Anabilim Dalı, KONYA - TURKEY

e-mail: necdetpoyraz@gmail.com 


\section{Giriş}

Plevra kaynaklı hastalıkların tanı ve tedavisinde konvansiyonel akciğer radyografisi yanında diğer radyolojik yöntemlerin önemli rolü vardır. Standart akciğer radyografisi birincil tanı yöntemidir. Klinik bulgulara bağlı olarak radyografiden sonra kullanılan inceleme yöntemleri ultrasonografi (USG) ve bilgisayarlı tomografi $(B T)^{\prime}$ dir. Plevra kaynaklı patolojilerin değerlendirilmesinde manyetik rezonans görüntülemenin (MRG) kullanımı sınırlıdır (1).

Bu derlemenin amacı plevra hastalıklarının tanısında konvansiyonel akciğer radyografisinin önemi ve karakteristik radyografik bulgularını ve USG, BT ve MRG yöntemlerinin tanıya katkılarını tanımlamaktır.

\section{Plevral Sivı}

Sağlıklı olgularda plevra boşluğunda $0.1-0.3 \mathrm{~mL} / \mathrm{kg}$ civarında sıvı bulunmaktadır (Örneğin, 70 kg'lık bir insanda her bir hemitoraksta $10-20 \mathrm{~mL}$ plevral sIvı vardır). Bu sıvı solunum hareketleri esnasında plevra yapraklarının serbest olarak hareket etmesini sağlamaktadır.

Deneysel çalışmalara göre plevral sıvının normal şartlarda pariyetal plevra seviyesindeki sistemik basınca sahip mikrovasküler dolaşımdan ekstraplevral interstisyuma geçtiği ve oradan düşük basınç farkı ile plevral boşluğa geçiş yaptığı belirtilmektedir. Plevral boşluğa gelen sıvı fizyolojik şartlarda pariyetal plevradan direne olmaktadır. Visseral plevranın plevral sıvı direnajına katkısı ihmal edilebilir $(2,3)$. Plevral sıvının (efüzyon) üretimi ve emilimi arasında devamlı bir denge vardır. Dolayısıyla plevral aralıkta fazla sıvı toplanması;

a. Plevra, akciğer veya lenfatik sistem sağlam iken hidrostatik basınç ve/veya onkotik basınç değişikliklerine bağlı olarak meydana gelebileceği gibi,

b. Plevrada, akciğerlerde veya lenfatik akımdaki patolojik değişikliklerde de plevral boşlukta sıvı toplanabilir.

Birinci gruptaki nedenlerle plevral boşluktaki toplanan sıvı transüda özelliğindedir. İkinci gruptaki nedenlerle plevral boşlukta toplanan sıvı ise protein ve hücre gibi elemanları içermektedir. Bu tip sıvılara eksüda adı verilmektedir (2). Transüda özelliğindeki sıvı birikimine neden olan en yaygın neden kalp yetmezliğidir. Plazmada onkotik basınç azalmasına, dolayısıyla hipoproteinemiye neden olan birçok patoloji transüda özelliğinde plevral sıvının oluşmasına yol açmaktadır. Infeksiyon hastalıkları, malign hastalıklar, pulmoner tromboemboli ve kollajen doku hastalıkları eksüda özelliğinde plevral sıvının oluşmasına neden olmaktadır.
Vertikal pozisyondaki olguda plevral sıvı akciğerin alt yüzeyi ile diyafragma arasında toplanır. Plevral boşluktaki sıvı $75 \mathrm{~mL}$ 'den az ise diyafragma ve kostofrenik sinüsler normal morfolojik yapıdadır. PA akciğer grafisi sıvının olduğunu göstermeyebilir. Sıvı belirli miktara ulaşınca önce posterior, sonra lateral kostofrenik sinüste kapanma görülür. Lateral kostofrenik sinüsün kapanması için plevral sıvı en az $175 \mathrm{~mL}$ olmalıdır. Posterior kostofrenik sinüs lateral kostofrenik sinüsten daha derin olduğu için az miktardaki sıvı yan radyografide posterior kostofrenik sinüsün kapalı olmasına neden olmaktadır (4-6). Plevral boşluktaki sıvı arttıkça etkilenen diyafragma yaprağı ve sinüslerin konturu silinir. Sıvı anterior, lateral ve posterior toraks duvarı boyunca plevral boşluğu doldurur. Mediastinal plevral boşluğa ise sıvının bir miktarı geçebilir. Çünkü akciğerin mediastinal yüzeyi hilus ve pulmoner ligament düzeyinde fiksedir. Plevral boşluktaki sıvının belirli miktara ulaşması ile PA ve yan radyografilerde açıklığı yukarıya bakan yoğunluk artışı parabolik eğri konfigürasyonu göstermektedir (Resim 1). Plevral boşluktaki sıvı hastanın pozisyonunun değişmesiyle yer değiştirebilir (serbest plevral sıvı). Masif plevral sıvıya rağmen mediastende karşı tarafa itilme yoksa akciğerde atelektazi veya kollapsın bulunduğunun işaretidir. Bu bulgu bronş kanserinde görülmektedir (Resim 2) (7).

USG serbest plevral sıvının solid özellikteki plevral lezyonlardan ayırt edilmesinde, radyografiden daha duyarlı olmasına rağmen, iki modalitenin birlikte kullanılması ile güvenirliliği artırmaktadır (\%98). Bu olgularda radyografinin güverliliği \%68, USG'nin ise \%92'dir $(1,8)$. Plevral boşluktaki sıvı yaklaşık $75 \mathrm{~mL}$ 'den az ise PA radyografide diyafragma normal

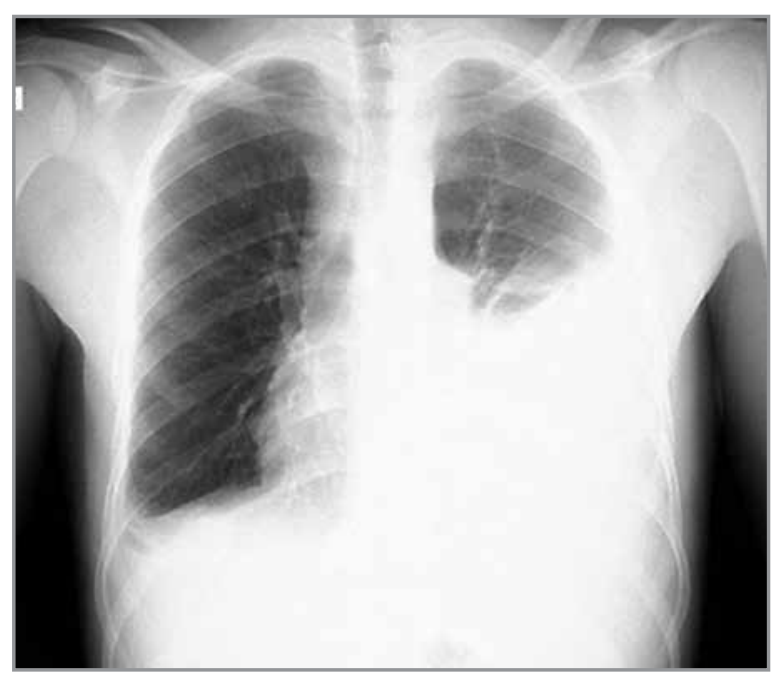

Resim 1. PA radyografide açıklığı yukarı bakan parabolik eğri konfigürasyonlu yoğunluk artışı: orta derecede plevral efüzyon. 

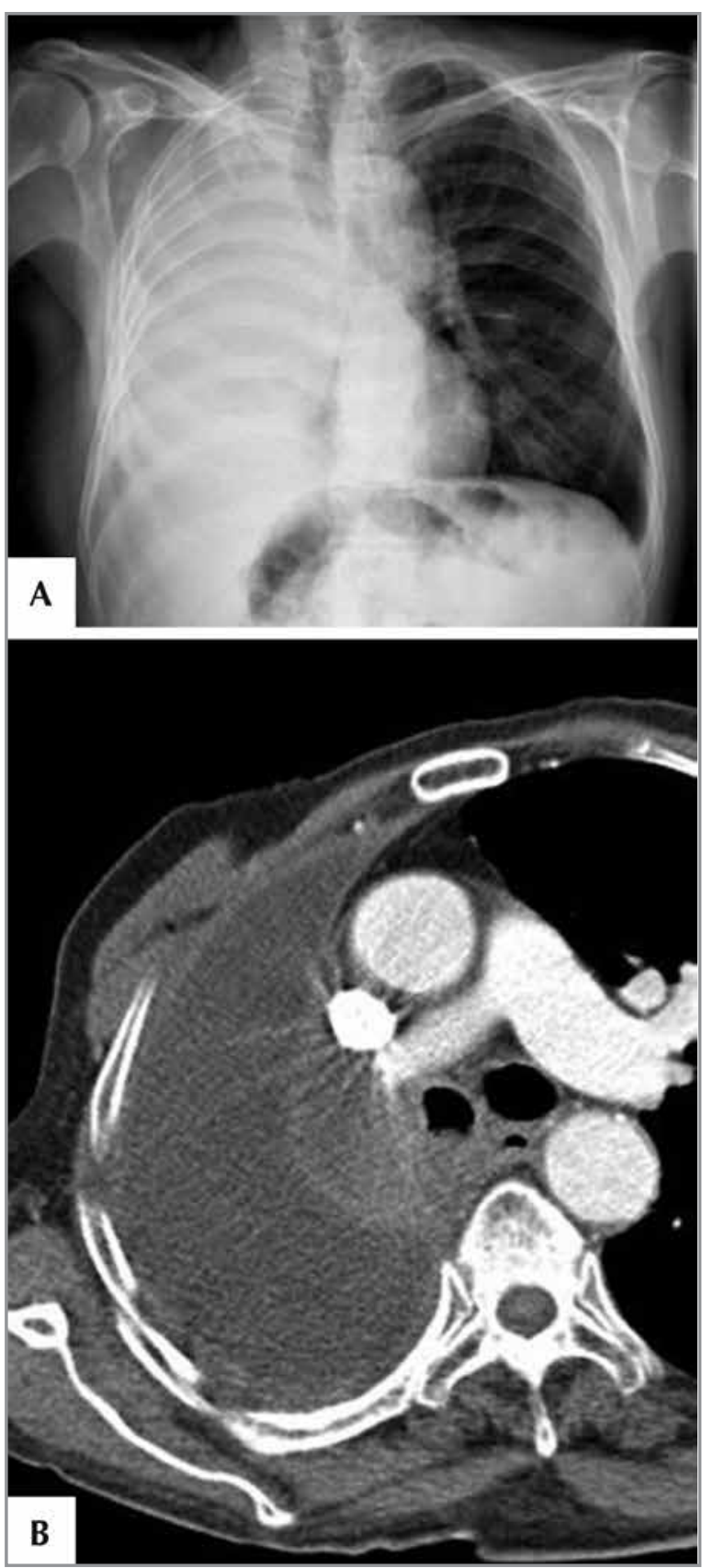

Resim 2. Total atelektazi ve plevral efüzyon. (A) PA radyografide sağ hemitoraksta homojen yoğunluk artışı, trakeada ve mediastende sağa doğru çekilme, (B) BT'de sağ hiler kitleye bağlı sağ akciğerde total atelektazi ve plevral efüzyon.

morfolojik yapıyı gösterir. Lateral dekübitus pozisyonundaki akciğer radyografisi 5-10 mL gibi az miktardaki plevral sıvıyı gösterebilir. Serbest plevral sıvı lateral dekübitus pozisyonunda toraks duvarı ile akciğerin alt kenarı arasında düzgün horizontal yoğunluk artışı ile karakterize homojen dansite artışı gösterir. Bu bulgu akciğerin sıvı içerisinde yer almasından kaynaklanır. Kaynaklarda bu pozisyon ile 5-15 mL kadar plevral sıvının gösterilebileceği belirtilmektedir $(4-6,9)$. Lateral dekübitus pozisyonunda toraks duvarı ile akciğer arasındaki mesafe $10 \mathrm{~mm}$ 'den az ise tanısal amaçlı torasentez nadiren yapılmaktadır (5). Kaynaklarda az miktardaki serbest plevral sıvının (kalınlığı $15 \mathrm{~mm}$ ) toraks USG ile gösterilebileceği belirtilmektedir (10).

\section{Atipik Plevral Sıvı}

Plevra yaprakları arasındaki yapışıklıklar nedeniyle plevral boşluktaki sıvı yer değiştirmediği için tabanı plevraya yerleşmiş kitleye benzer bulgu verebilir (ankiste-loküle plevral sıvı). Bu görünüm ampiyem, hemotoraks veya tüberküloz plörezi gibi yoğun plevral infilamasyonlarda görülmektedir $(1,4,5,7)$. Loküle plevral sıvı lateral dekübit radyografide yer değiştirmez. Ultrasonografi ve BT bu tip patolojilerde daha yararlı olmaktadır $(5,7)$. Konjestif kalp yetmezliğinde sıklıkla interlober fissürde sıvı toplanmaktadır. Minör veya majör fissürde toplanan sıvı konveks konturlu, oval veya yuvarlak sınırları muntazam opasite şeklinde görülmektedir (Resim 3). Bu bulguya fantom tümör-yalancı tümör bulgusu (vanishing tümör) adı verilmektedir $(7,11,12)$.

\section{Subpulmoner Plevral Sıvı}

Plevral sıvı bazen akciğerin alt yüzeyi ile diyafragma yaprağı arasında toplanmaktadır (Resim 4). Tek taraflı veya iki taraflı olabilir. Subpulmoner plevral sıvı olasılığını dışlamak için lateral dekübit grafi çekilmelidir. Başlıca radyolojik bulgular;

a. Tek taraflı veya iki taraflı diyafragma kubbesinde yükselme,

b. Diyafragmanın en yüksek noktası, orta hatta olması gerekirken diyafragmanın 1/3 orta ve $2 / 3$ lateral birleşimine yakın ve daha lateralde lokalizedir.

c. Diyafragma kubbesi lateral kostofrenik açıya doğru daha keskin eğim gösterir,

d. Subpulmoner sıvı solda lokalize ise diyafragma ile mide hava cebi arasındaki mesafe $2 \mathrm{~cm}$ 'den fazladır,

e. Lateral radyografide subpulmoner sıvı, alt lobun altında yatay çizgi şeklinde görülür. Sıvıya ait bu çizgi önde major fissür düzeyinde dik olarak aşağıya iner,

f. Pulmoner vasküler yapılar diyafragma konturunun arkasında izlenmesi gerekirken subpulmoner sıvının oluşturduğu yalancı kontur "psödodiyafragmatik kontur"un arkasında vasküler yapılar görülmez,

g. Kostofrenik sinüsler kapalıdır (4-6). 


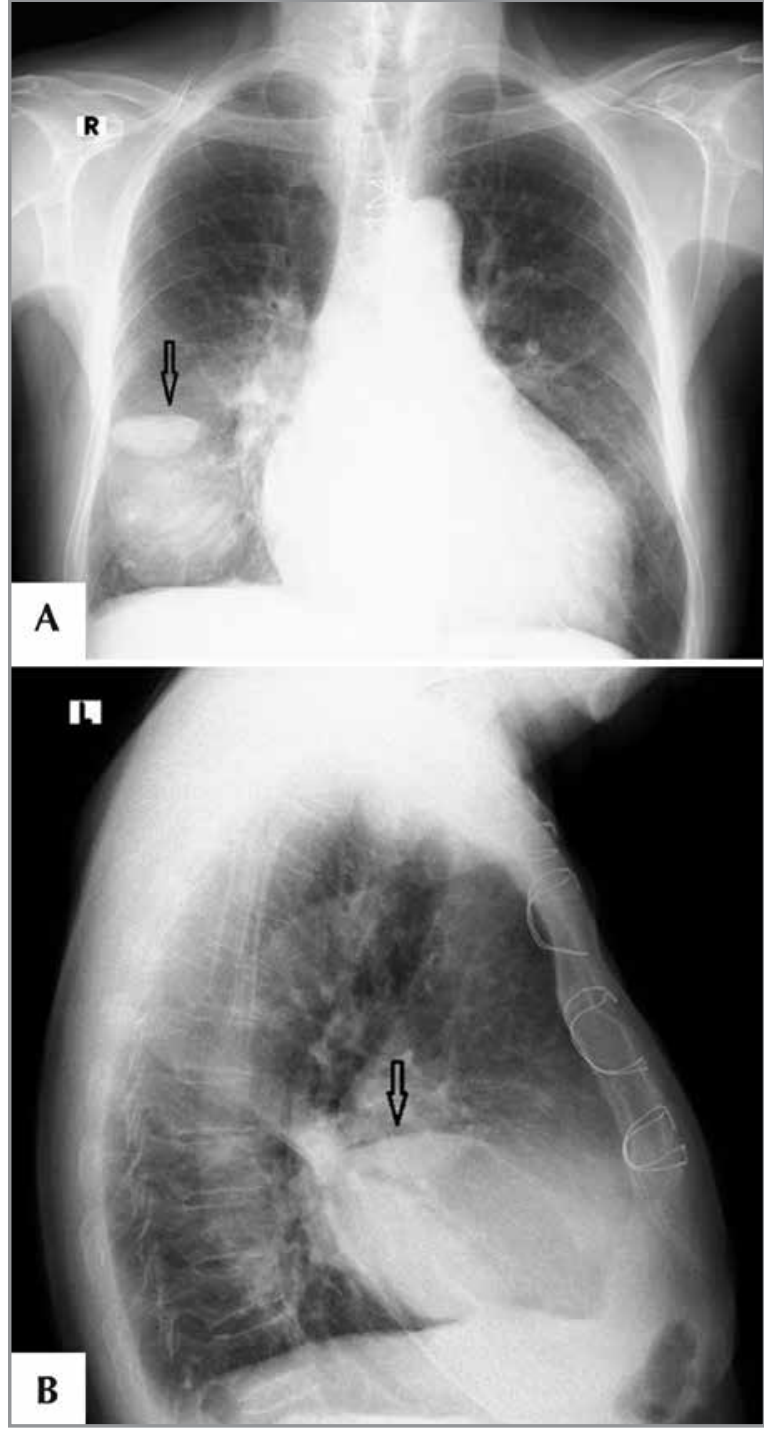

Resim 3. Interlober fissürde sıvı koleksiyonu (fantom tümörü) (A) PA, (B) Sağ yan radyografide minör fissürde konveks konturlu sıvı koleksiyonu (ok).

Yoğun bakım ünitelerinde ve çoklu organ yaralanması gösteren olgularda akciğer radyografisi yatak başında yatar pozisyonda (supine pozisyonu) elde edilmektedir. Supine pozisyonunda plevral sıvı yer çekimine bağlı olarak akciğerin dependan bölümünde lokalize olmaktadır. Bu pozisyondaki radyografide başlıca bulgular (Resim 5);

a. Kostofrenik sinüslerde kapanma,

b. Tek taraflı olarak homojen yoğunluk artışı,

c. Diyafragma konturunda silinme,

d. Akciğerin apikal alanında yarım ay şeklinde dens band izlenir (apikal capping),

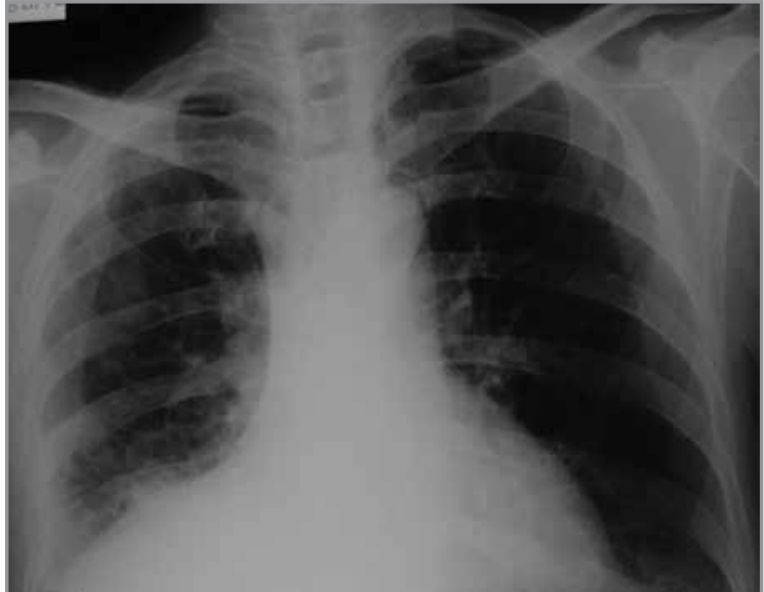

A

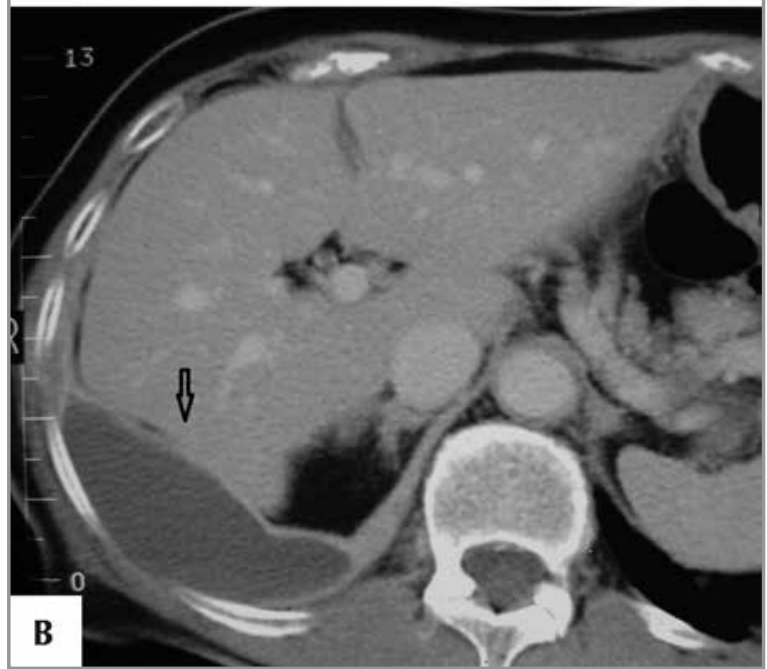

Resim 4. Subpulmoner plevral sivı. (A) PA radyografide kalbin sağ kenarı ve diyafragma kenarı izlenmiyor, (B) BT'de subpulmoner sıvı koleksiyonu (ok).

e. Alt lob düzeyinde vasküler yapıların görülmesinde azalma ve minör fissürde belirginleşme.

Az miktarda ve orta miktardaki plevral sıvı bulunan olgularda bu bulgular her zaman görülmeyebilir. Kaynaklarda belirtilen bulguların görülme oranı $\% 50.6$ 'dan \%97'ye kadar değişmektedir (5,13-15). Az miktarda ve orta miktardaki plevral sıvıların saptanmasında supine ve oturur pozisyondaki (semierekt) radyografilerin duyarlılığı düşüktür. Plevral sıvı parankimal lezyon olarak tanımlanabilir. Bu olgularda radyografi, USG ve BT kadar duyarlı değildir (16).

\section{Plevra Kalınlaşması}

Plevradaki inflamasyondan sonra plevranın kalınlığı 1-10 mm olabilir. Plevranın inflamasyonundan sonra 


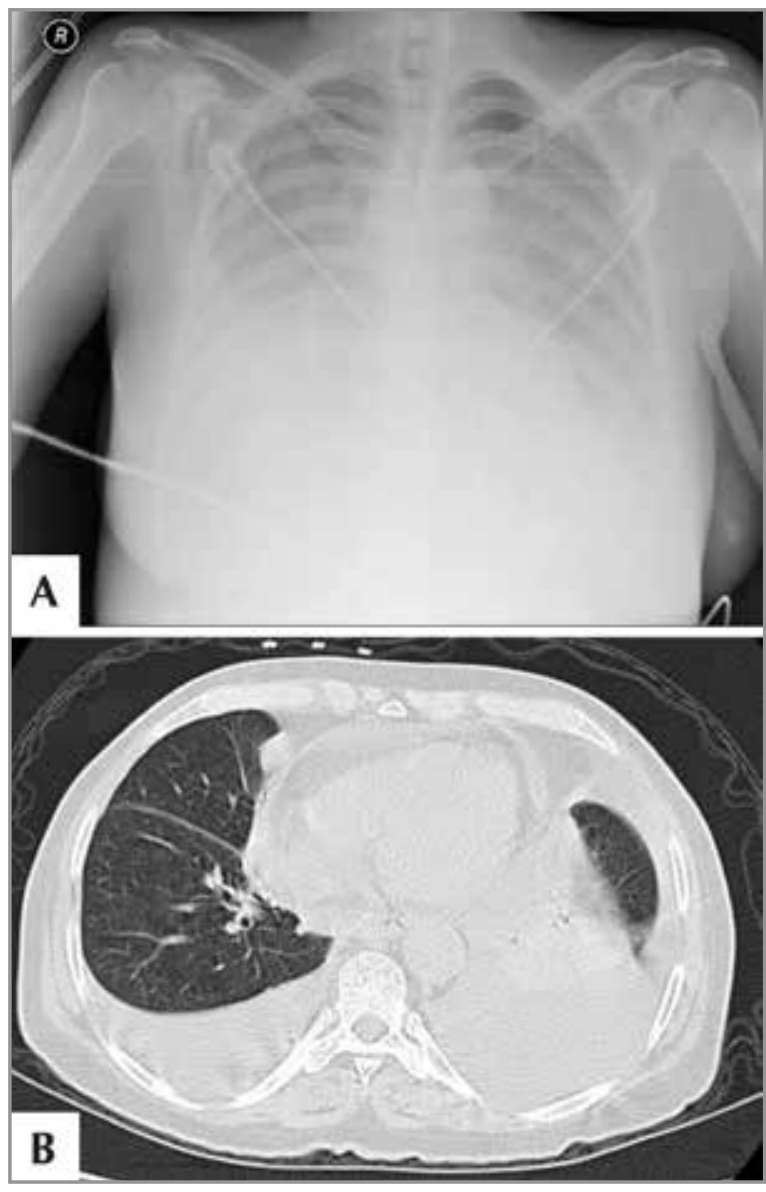

Resim 5. Yoğun bakım ünitesindeki olguda supine radyografi ve BT bulguları (A) Supine radyografisinde iki taraflı yoğunluk artışı görülüyor. (B) BT'de iki taraflı plevral efüzyon ve solda kompresyon atelektazisi.

oluşan plevral kalınlaşma visseral plevra yüzeyindeki fibrozis nedeniyle meydana gelir. Plevral kalınlaşma lokalize veya yaygın olabilir. Bu olgularda plevral sıvıyı dışlamak için lateral dekübit radyografisi, USG veya BT yapılmalıdır. Masif hemotoraks, piyotoraks (ampiyem), tüberküloz plörezi nedeniyle yaygın plevral kalınlaşma meydana gelir (Resim 6) $(5,7,17)$. Akciğer radyografisinde lateral ve posterior kostofrenik sinüslerde kapanma vardır. Pariyetal plevradaki kalınlaşma sonucunda birkaç milimetre veya daha fazla kalınlıkta akciğeri kostalardan ve göğüs duvarından ayıran fokal veya yaygın yumuşak doku dansite artışı görülmektedir (17). Visseral plevra ve pariyetal plevra kalınlaşması sıklıkla, plevral sıvı ile birlikte bulunmaktadır ve en sık nedeni ampiyemdir. Visseral plevra kalınlaşmasının en sık nedeni ampiyemdir. Radyografide genellikle visseral plevra kalınlaşmasını pariyetal plevra kalınlaşmasından ayırt etmek güçtür. Fissür kalınlaşması görülürse, pnömotoraks görülen

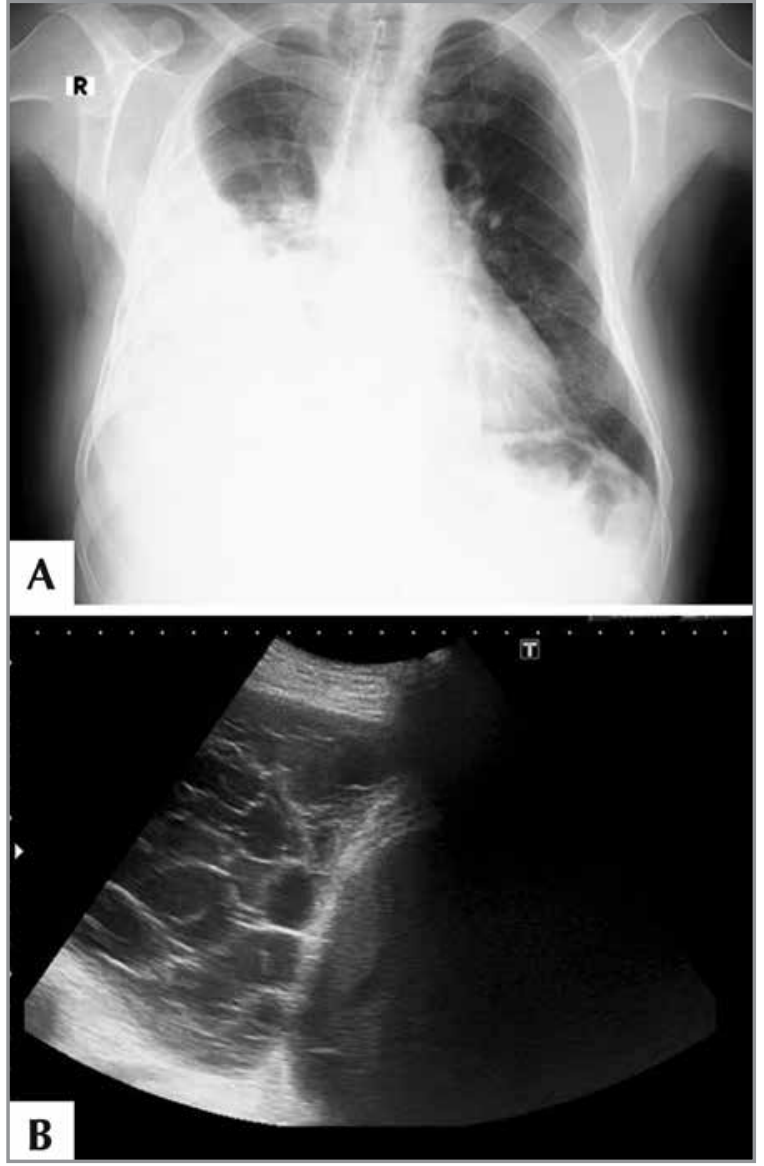

Resim 6. Tüberküloz plörezi ve plevra kalınlaşması. (A) PA radyografide sağda masif plevral efüzyon, (B) Toraks USG'de plevrada kalınlaşma ve kompleks (multiloküle) septalı plevral sıvı. Tanı: Torasentezle aspire edilen sıvının biyokimyasal analizi ile tanı konuldu.

bir akciğer yüzeyinde plevral kalınlaşmanın görülmesi halinde visseral plevra kalınlaşmasından bahsedilebilir. Kontrastlı BT'de akciğerin yüzeyinde kontrast madde ile boyanan bir çizgi görülmesi halinde visseral plevranın kalınlaştığını söylemek mümkündür. Kalınlaşmış visseral plevra hava içermeyen akciğerlerden daha fazla boyanmaktadır. Akciğer apeksinde görülen plevral kalınlaşma genellikle tüberküloz infeksiyonuna bağlı fibrozis gösteren olgularda tek taraflı veya iki taraflı görülmektedir. Ayrıca kronik iskemik olaylardan sonraki iyileşme sürecinde de apikal alanlarda fibrozis görülmektedir. Apikal alanda görülen fibrozis ile ayırıcı tanıda Pancoast tümörü düşünülmelidir (5).

\section{Difüz Plevral Fibrozis}

Göğüs duvarının en az 1/4'ü boyunca kesintisiz olarak uzanan ve plevranın iki tabakasını da etkileyen kalınlaşma şeklinde tanımlanmaktadır. Plevral kalın- 
laşma $2 \mathrm{~cm}$ ya da $1 \mathrm{~cm}$ 'den az olabilir. Difüz plevral kalınlaşmaya (fibrotoraks) bağlı olarak plevral boşluğun fibröz dokuya bağlı oblitere olması sıklıkla tüberküloz plörezisi, bakteriyel infeksiyona bağlı ampiyem, hemotoraks, üremi, pankreatit, kollajen doku hastalıkları ve asbest temasına bağlı olarak meydana gelir $(1,18)$. Fibrozisle birlikte kalsifikasyon görülmesi halinde kronik ampiyem, hemotoraks, tüberküloz plörezi sekeli, edinsel pnömotoraks ve asbest maruziyeti düşünülmelidir (Resim 7) (19).

\section{Asbest Temasına Bağıı Plevra Hastalıkları}

Asbest lifsi yapıda (uzunluğu 10 mikrometre) mineral olup ıSı, su ve strese yüksek dayanıklı bir maddedir. Bu özelliği nedeniyle değişik iş kollarında ara madde
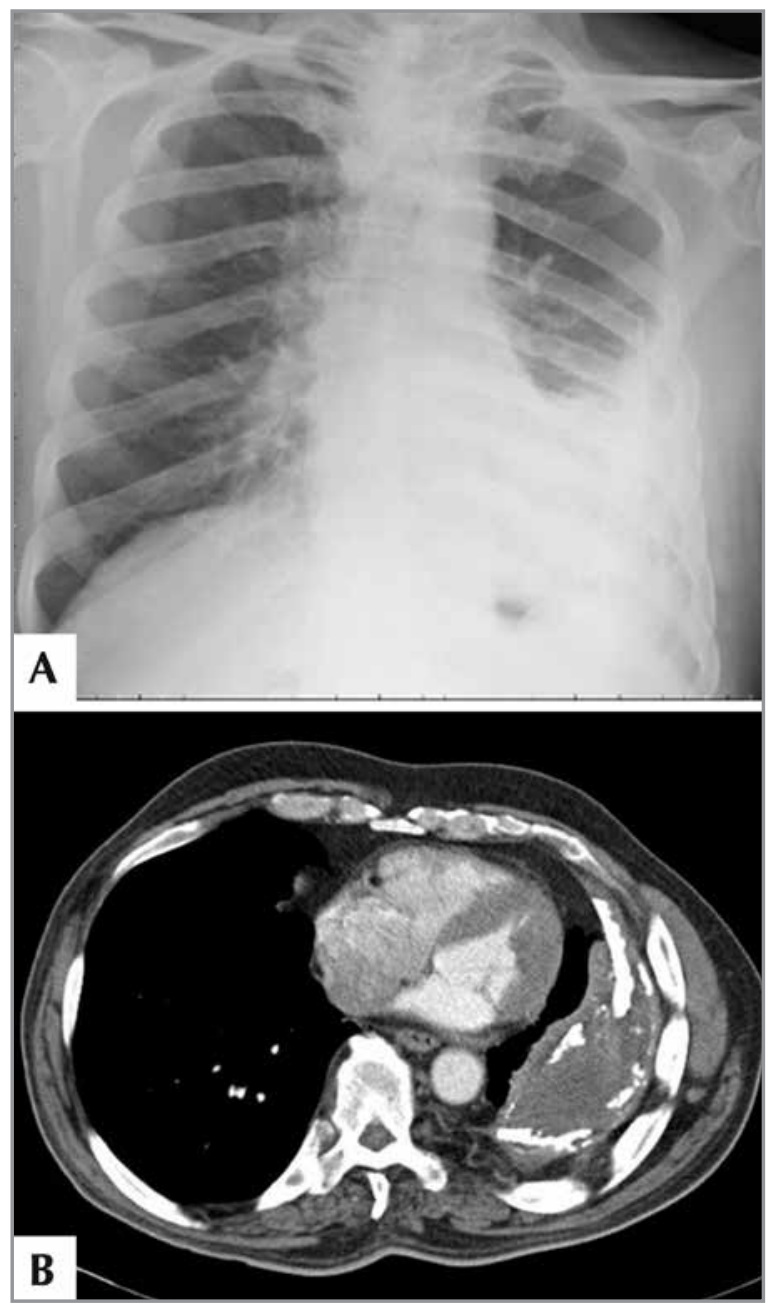

Resim 7. Tüberküloz plörozi sekeline bağlı difüz plevra kalınlaşması ve kalsifikasyon. (A) PA radyografide solda göğüs duvarı boyunca plevrada kalınlaşma, (B) BT'de sol göğüs duvarı boyunca plevrada düzensiz kalınlaşma ve kalsifikasyon. olarak kullanılmaktadır. i̇ç Anadolu, Güneydoğu Anadolu ve Doğu Anadolu bölgelerinde kırsal kesimde asbest içeren ak toprak veya çorak olarak adlandırılan toprak ısı ve su yalıtım amacıyla evlerin çatısında örtü ve duvarlarında badana olarak kullanılmaktadır. Ak toprak içerdiği asbest lifleri nedeniyle kırsal alanlarda yaşayanlarda doğumdan itibaren asbest temasının oluşmasına neden olmaktadır. Asbest temasına bağlı meydana gelen hastalıklar; plevral plaklar, benign plevral efüzyon, yaygın plevral kalınlaşma, yuvarlak atelektazi ve malign plevral mezotelyomadır $(20,21)$.

Asbest liflerine uzun süre ve yüksek konsantrasyonda maruz kalma sonucunda parankimde fibrozise (asbestozis), düşük konsantrasyonda ve aralıklı maruz kalmada ise plevra hastalıkları daha sık görülmektedir. Asbest lifleri solunum yoluyla inhale edildikten sonra peribronkovasküler interstisyumdaki boşluklardan subplevral alana ilerlemekte ve buradan da mezotel hücreleri yoluyla plevral boşluğa ulaşmakta$\operatorname{dir}(20,22,23)$.

\section{Plevra Plakları}

Asbest temasının en yaygın bulgusudur. Bu bulgu asbest temasından 20 yıl veya daha fazla süre geçmeden PA radyografide görülmeyebilir. Plevral plaklar öncelikle pariyetal plevranın veya göğüs duvarının posterolateralinde 7 ve 10 . kostalar arasında, lateral göğüs duvarında 6 ve 9. kostalar arasında, diyafragma kubbesinde plato şeklinde, düzgün veya nodüler plevral kalınlaşmalar şeklinde görülmektedir. Genellikle plaklar pariyetal plevrada görülmesine rağmen visseral plevrada da görülebilir. Plevral plakların gösterilmesinde oblik radyografiler yararlıdır (20-23). Plaklar lateral pozisyonda yan gögüus duvarının iç yüzeyine paralel, kalınlığı 1-10 mm olan yumuşak dansitede sınırları belirli dens bant şeklinde görülebilir. Frontal pozisyonda plaklar sınırları belirsiz peçe veya örtü şeklinde görülür. Kaynaklarda plevral plakların düşük oranda postmortem olarak saptandığı belirtilmektedir $(23,24)$.

\section{Difüz Plevra Kalınlaşması (Fibrotoraks)}

Göğüs duvarı boyunca uzanan kesintisiz düzgün dansite artışı şeklinde görülür. Asbestozlu olgularda göğüs duvarının en az 1/4'ü boyunca plevrada görülen kalınlaşma şeklinde tanımlanmaktadır. Kostofrenik sinüste tutulum görülebilir. Plevradaki kalınlaşma 2 $\mathrm{cm}$ veya daha fazladır, ancak genellikle $1 \mathrm{~cm}$ 'den azdır. Fibrotoraks olgularında ayırıcı tanıda tüberkü- 
loz plörezi, ampiyem, hemotoraks, kollajen doku hastalıkları ve üremiye bağlı plevral kalınlaşma düşünülmelidir $(1,18,19,22,23)$.

\section{Benign Asbest Plörezisi}

Asbest temasının erken bulgusudur. Plevral sıvı genellikle az miktarda ve tek taraflıdır. Tanı zorluğu olmasına rağmen, benign plevral efüzyonun asbest teması olan olguların ilk 20 yılında görülmektedir (23).

\section{Kalsifiye Plevra Plakları}

Plevrada lokalize plaklarda görülmektedir. Sıklıkla asbest temasından 30-40 yıl sonra gelişmektedir. Kalsifikasyonlar göğüs duvarı boyunca, diyafragma kubbesinde veya kalp konturu boyunca lokalize olmaktadır. Frontal pozisyonda (anfaz) düzensiz kenarlı çınar ağacı yaprağına benzer (holly leaf) bulgu vermektedir (Resim 8). Oblik radyografiler parankimde lokalize nodüler lezyonlardan ayırt edilmesinde yararlı olabilir (23). Plevral kalsifikasyon saptanan olgularda ayırıcı tanıda ampiyem, tüberküloza bağlı plevra tutulumu ve travmatik hemotoraks düşünülmelidir (5).

\section{Yuvarlak Atelektazi}

Asbest teması nedeniyle plevrada oluşan fibrotik süreç akciğer parenkimini de etkileyerek atelektaziye neden olabilir. Atelektazik akciğer dokusuna bağ $\left.\right|_{ı}$ kitle veya opasite ile birlikte kitleye doğru uzanan

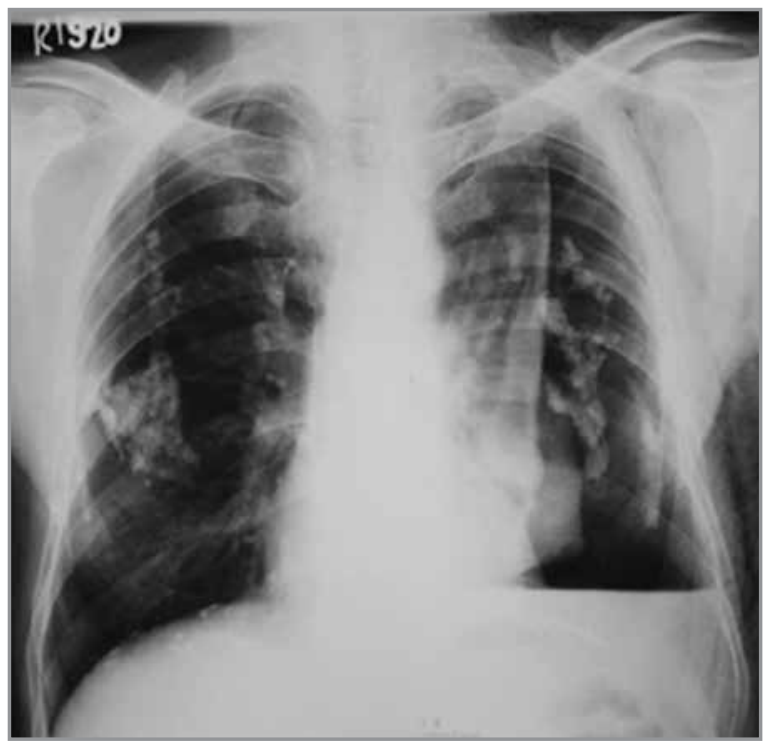

Resim 8. Asbestoza bağlı plevrada kalsifiye plaklar. PA radyografide solda hidropnömotoraks ve iki taraflı pariyetal plevrada çınar ağacı yaprağına benzer (holly leaf) kalsifiye plaklar. damarlar ve bronşlarla beraber kuyruklu yıldız (comet-tail sign) bulgusu meydana gelmektedir (Resim 9) $(18,22,23)$.

\section{Ampiyem}

Plevra yaprakları arasında veya interlober fissürlerde pürülan özellikteki sıvının toplanmasıdır. Ampiyem serbest plevral sıvı veya loküle şeklinde olabilir. Bakteriyel pnömoninin ve akciğer apsesinin seyri esnasında, septik emboliden, cerrahi girişimden sonra ayrıca mediastinal apseden, subfrenik apseden ve travma gibi nedenlerden dolayı da meydana gelebilir. Parapnömonik sıvıda olduğu gibi ampiyemin kesin tanısı plevral sıvının torasentezle direne edilmesine ve sıvının biyokimyasal analizine dayanır. Akciğer radyografisinde ampiyem serbest plevral

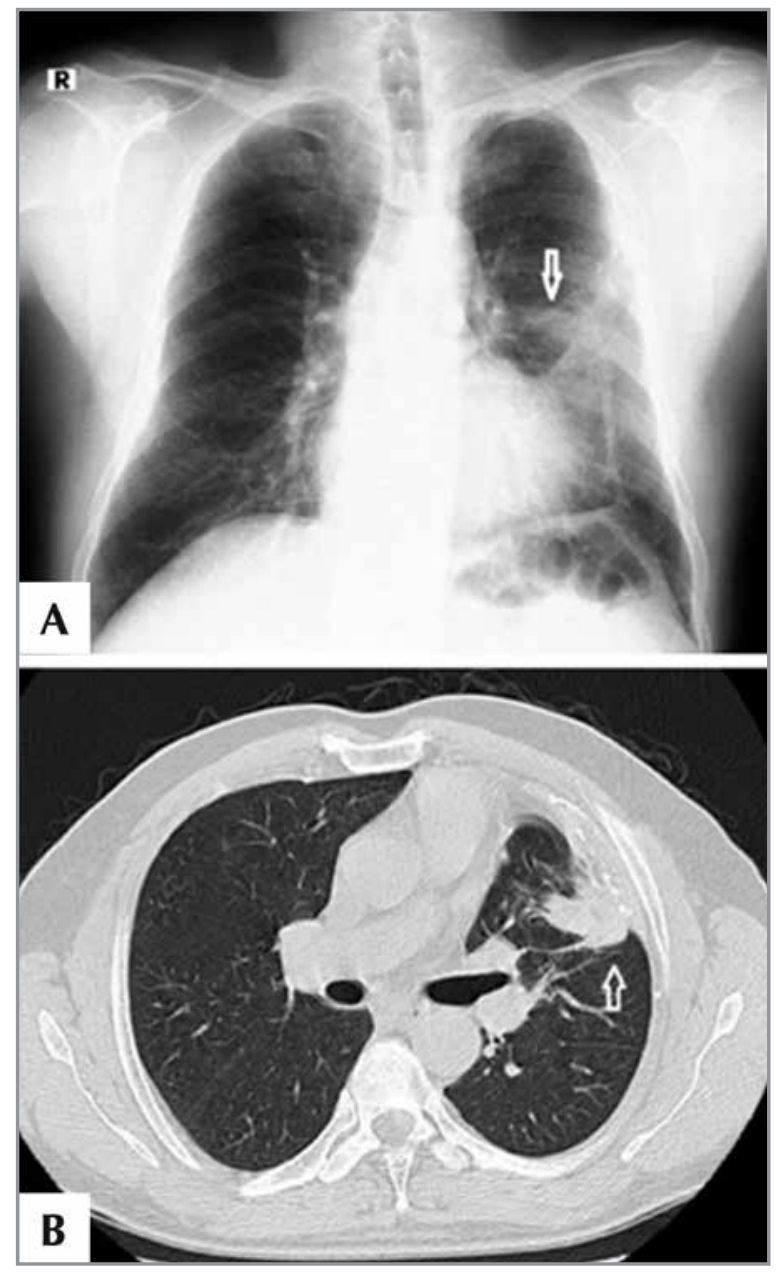

Resim 9. Kronik plevra infeksiyonuna bağlı yuvarlak atelektazi. (A) PA radyografide sol hilus periferinde dansite artışı ve sol diyafragmada çekilme (B) BT'de sol göğüs duvarında kalsifikasyon içeren plevra kalınlaşması ve subplevral alanda düzensiz konturlu kitle (kuyruklu yıldız-comet tail bulgusu) (ok). 
sıvıya benzemekte ve meniskus bulgusu görülmektedir. Ancak lobule konturlu olmaya eğilim gösterir veya konveks kontur gösterebilir. Bu bulgularla akciğer apsesinden ayırt edilebilir. Bronkoplevral fistül varsa hava-sıvı seviyesi görülebilir $(1,25)$. Ampiyema necessitates kronik ampiyemin gögüs duvarına uzandığını gösterir (26). Kronik seyir gösteren ampiyemli olgular USG'de plevral kalınlaşma ile birlikte septalı kompleks yapı gösterebilir $(7,17)$. Bu olgularda göğüs tüpü ile direnaj veya cerrahi girişim olası değildir. Ayırıcı tanıda tüberküloz plörezi düşünülmelidir. Kontrastlı BT'de kalınlaşan plevra yapraklarının (split plevra bulgusu) arasında sıvının bulunması organize ampiyemin geliştiğini belirtir (7). Yetişkin yaşlarda kronik akciğer tüberkülozuna bağlı ampiyem tanılı olgularda plevrada kalsifiye plak veya periferik kalsifikasyon görülebilir (26)

\section{Pnömotoraks}

Plevra yapraklarının arasında pozitif basınçlı havanın toplanmasıdır. Hava plevral boşluğa göğüs duvarı, mediasten ve diyafragma yoluyla veya visseral plevranın yırtılması sonucunda girebilir. Travmadan veya tanı ve tedavi amacıyla yapılan işlemlerden dolayı olmayan pnömotoraksa spontan pnömotoraks adı verilmektedir.

Spontan pnömotoraks: Primer, sekonder ve neonatal olmak üzere üçe ayrılmaktadır. Primer spontan pnömotoraksa (PSP) idyopatik veya benign pnömotoraks adı verilmektedir. Sağlıklı ve genç olgularda altta yatan herhangi bir hastalık olmadan meydana gelen pnömotoraksa benign spontan pnömotoraks adı verilmektedir. Ancak bu tip pnömotoraksın en yaygın nedeni subplevral bleb veya bülün plevral boşluğa rüptüre olmasıdır $(27,28)$. PSP \%23-52 oranında 2 yıl içinde tekrar görülmektedir (28-30).

Sekonder spontan pnömotoraks ise akciğer parankiminde lokalize predispozan nedenlere veya konjenital patolojilere, KOAH gibi edinsel hastalıklara, bağ doku hastalıklarına (Ehlers-Danlos sendromu, Marfan sendromu) ve akkiz immün yetmezlik sendromu (AIDS) hastalığına bağlı olarak meydana gelir (Resim 10) $(5,27,28,30)$.

Neonatal pnömotoraks, çocuklarda kistik akciğer hastalığında, mekonyum aspirasyonu, kan veya mukus aspirasyonu ile birlikte güç doğumlarda ve resussitasyon gerektiren sıkıntılı solunum sendromlu (ARDS) bebeklerde görülmektedir. Ayırıcı tanıda hyalin membran hastalığı, aspirasyon pnömonisi, akciğerin konjenital kistleri, lober amfizem ve diyafragma hernileri düşünülmelidir (28).
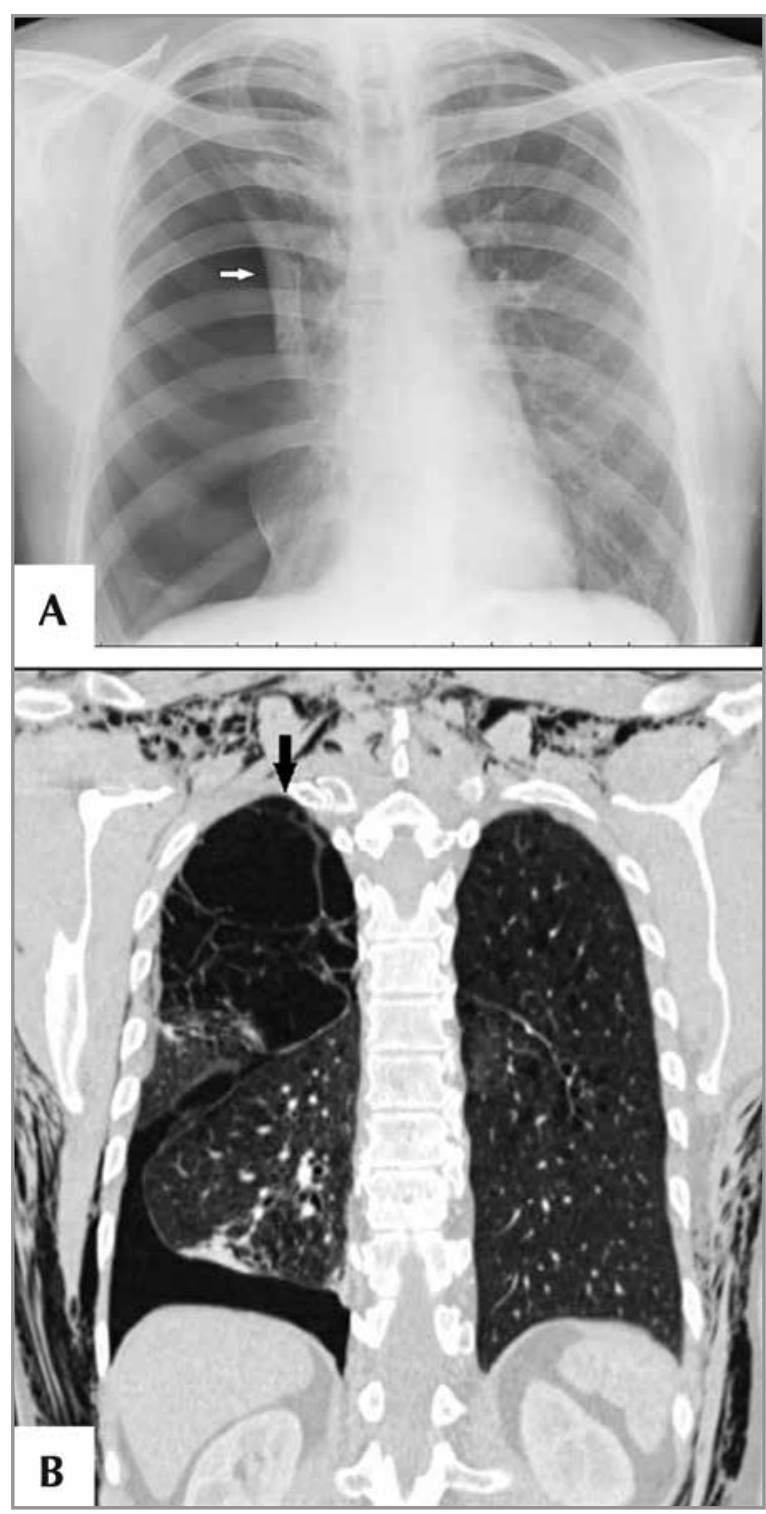

Resim 10. Sekonder spontan pnömotoraks, (A) PA radyografide sağda radyolüsent plevral boşluk ve visseral plevra (ok), (B) BT'de (koronal reformat görüntü). Sağ akciğerde birçok sayıda büller ve pnömotoraks bulgusu.

Katemenial pnömotoraks, kadınlarda menstrüel siklus esnasında vajina, uterus ve fallop tüpleri yoluyla havanın plevral boşluğa geçmesiyle oluşmaktadır. Ayrıca pelvik endometriozis tanılı olgularda da aynı bulgular görülmektedir.

\section{Edinsel Pnömotoraks}

Travmatik pnömotoraks: Künt ve penetran travma nedeniyle ana bronşun yırtılması veya akciğer laserasyonu sonucunda oluşmaktadır. Künt travmaya bağlı kosta kırığı ya da dislokasyon visseral plevrayı 
yırtarak pnömotoraksa neden olabilir. Hidropnömotoraks, disfaji ve pnömomediastinumun bulunması halinde özefagus yırtılması düşünülmelidir $(27,28)$.

İyatrojenik pnömotoraks: Tanı ve tedavi amacıyla yapılan girişimlere bağlı olarak oluşmaktadır. Sıklıkla transtorasik iğne aspirasyonu veya biyopsi nedeniyle oluşmaktadır. Santral venöz kateter uygulanması esnasında (\%3-6) ve torasentezden sonra kronik obstrüktif akciğer hastalığı $(\mathrm{KOAH})$ olan olgularda (\%41) pnömotoraks daha sık görünmektedir.

Barotravmatik pnömotoraks: Mekanik ventilasyon esnasında \%50 oranında pnömotoraks gelişmektedir. Aspirasyon pnömonisinde bu oran \%35'e kadar çıkmaktadır $(27,28)$.

Pnömotorakta radyolojik bulgular: PA akciğer radyografisinde plevral boşlukta pozitif basınçlı havanın toplanması ile akciğerin pariyetal plevradan ve göğüs duvarından ayrılması sonucunda visseral plevra opak çizgi şeklinde görülmektedir. Kollabe akciğer hiler bölgeye doğru toplanmaktadır. Lateral dekübit grafi, PA akciğer grafisine göre daha duyarlıdır. Pnömotorakstan kuşku duyulan olgularda inspiryum radyografisi yeterli değilse, ekspiryum radyografisi ile tanı konulabilir. Hasta cildindeki ve elbisesindeki kıvrımlar ve göğüs tüpüne bağlı artefaklar visseral plevraya benzer bulgu verebilir. Ayrıca parankimdeki subplevral blep, kavite ve bül gibi lezyonlar da yanılgıya neden olabilir $(7,18,25,27)$. Travmalı olgularda radyografide küçük boyuttaki pnömotoraks ve kosta kırıkları görülmeyebilir (okkült pnömotoraks). Bu olguların \%5'inde pnömotoraks vardır ve bunların da \%40'ında okkült pnömotoraks bulunduğu belirtilnektedir (28). Bu olgularda BT daha ayrıntılı bilgi vermektedir. Supine pozisyonundaki radyografide havanın akciğerin ön bölümünde toplanması nedeniyle orta derecedeki pnömotoraks görülmeyebilir.

\section{Travmatik olgularda supine pozisyonundaki} radyografide pnömotoraks bulguları:

a. Hipokondrium bölgesinde veya tüm hemitoraksta radyolüsensi vardır,

b. Mediasten ve diyafragma sınırlarında artan keskin kontur bulgusu,

c. Hava kostofrenik sinüslerde toplandığı için derin radyolüsent kostofrenik sinüs bulgusu (derin sulkus bulgusu),

d. Yeni doğanlarda ve bebeklerde supine radyoğrafisinde kuşkulu bulgu varsa diğer pozisyonlardaki radyografiler gözden geçirilmelidir (18,31-33).

\section{PNÖMOTORAKSIN KOMPIKASYONLARI}

\section{Tansiyon Pnömotoraks}

Pnömotoraks gelişen olgularda görülebilen klinik tablodur. Solunum siklusu boyunca intraplevral basıncın atmosfer basıncını aşması durumudur. Her inspirasyonda toraks duvarından veya akciğerden intraplevral boşluğa giren hava ekspirasyonda çıkamazsa tansiyon pnömotoraks meydana gelmektedir. Plevral boşluğa hava girmesine neden olan lezyon, tek yönlü valf mekanizması oluşturmakla suçlanmaktadır. Plevral boşluktaki basınç atmosfer basıncının üzerine çıkması ile akciğer tamamen kollabe olur. Mediastende karşı tarafa itilme, tek taraflı hemitoraksta genişleme ve diyafragmada düzleşme görülür (30).

\section{Hidropnömotoraks}

Pnömotorakslı olguların \%20-50'sinde pnömotoraksla birlikte plevral boşlukta berrak sıvı, kanla karışık seröz sıvı veya kanlı sıvı bulunabilir.

\section{Re-ekspanse Pulmoner Ödem}

Pnömotoraks nedeniyle direnaj işleminden sonra kollabe akciğerin hızlı bir şekilde ekspanse olmasıyla birlikte tek taraflı olarak akciğerde pulmoner ödem meydana gelir.

\section{Pnömomediastinum}

Yeni doğanlarda ve travmalı olgularda trakeada veya büyük hava yollarında ve özefagusta yırtılma sonucunda pnömotoraks ile birlikte pnömomediastinum görülebilir.

\section{PARAZIT KAYNAKLI PLEVRA HASTALIKLARI}

\section{Amebiyazis}

Etkeni Entamoeba histolytica olan amebiyazis insanlarda en sık görülen paraziter hastalıklardan birisidir. Genellikle amipli dizanteri veya karaciğer apsesi şeklinde görülmektedir. Plöropulmoner amebiyazis sıklıkla karaciğer apsesinin komlikasyonuna bağlı olarak meydana gelir. Başlıca bulgular; plevral efüzyon, karaciğer apsesine bağlı akciğer parankim tutulumu, hepatobronşial fistül ve izole amebik akciğer apsesidir. PA radyoğrafide sağ diyafragmada yükselme, plevral efüzyon ve parankim tutulumu görülmektedir (34). Plevral efüzyon daima karaciğer amebiyazisinin toraksa yayılmasıla meydana gelir. Amebiyazisli olguların $\% 62$ 'sinde sadece plevral bulguların ve \%92 sinde kombine plöropulmoner bulguların bulunduğu belirtilmektedir (35). Kesin yanı klinik bulgularla birlikte 
serolojik, görüntüleme bulguları ve histopatolojik bulgularla konulmaktadır (34).

\section{Hidatik Kist Hastalı̆̆}

Hidatik kist nadiren plevral boşlukta ve interlober fissürde lokalize olmaktadır (primer plevral hidatidozis). Evcil köpeklerin neden olduğu hidatik kistle infekte olgularda sık görülmemektedir (36). Plevral boşlukta ve interlober fissürdeki intakt hidatik kist PA radyografide homojen yoğunluk artışı göstermektedir (Resim 1). USG'de ekoik kapsüllü sıvı içeren anekoik kistik lezyon şeklinde görülmektedir. $\mathrm{BT}^{\prime \prime}$ de diğer organlarda görülen bulgulara benzer şekilde kapsüllü SIVı içeren düşük dansiteli kistik lezyon şeklinde görülmektedir. MR görüntüleme yumuşak doku kont-

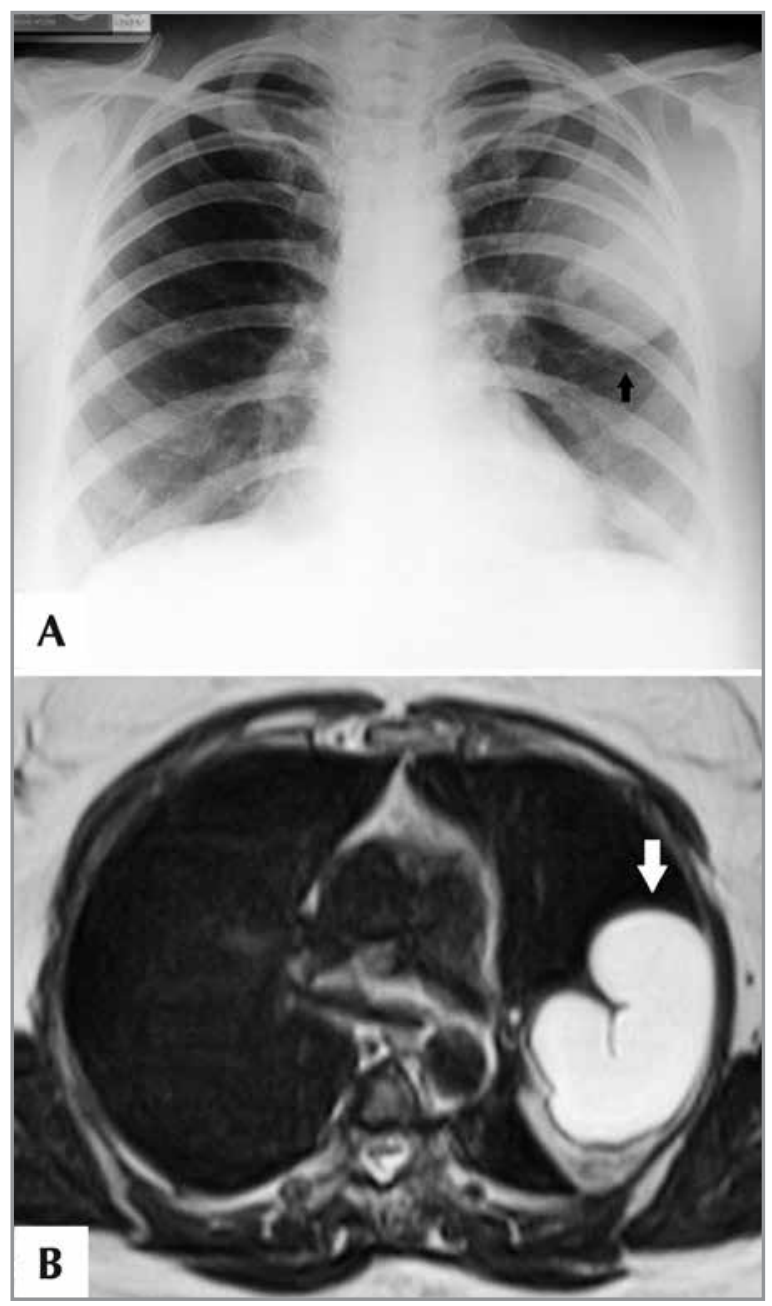

Resim 11. Interlober fissürde intakt hidatik kist, (A) PA radyografide solda üst zonda lokalize lobüle konturlu opasite (ok), (B) T2 ağırlıklı MR görüntülemede hipointens rim şeklinde kapsülü bulunan hiperintens sinyal intensiteli lobüle konturlu hidatik kist (ok). rast özelliğine bağlı olarak gerek plevral boşluktaki, gerekse interlober fissürdeki kistik lezyonu diğer yöntemlere göre daha ayrıntılı göstermektedir $(37,38)$. Plevral boşluktaki intakt hidatik kist spontan olarak veya travma nedeniyle perfore olabilir Germinatif membranın perikistten ayrılması ile perfore hidatik kist için oldukça spesifik bulgu olan görünüm meydana gelmektedir. Bu olgularda PA radyografide plevral efüzyona benzer bulgu ve hava-sıvı seviyesi görülebilir. Bu olgularda yumuşak doku kontrast özelliği ve üç boyutlu görüntüleme özelliği nedeniyle MRG daha ayrıntılı bilgi vermektedir (Resim 12) $(37,38)$.

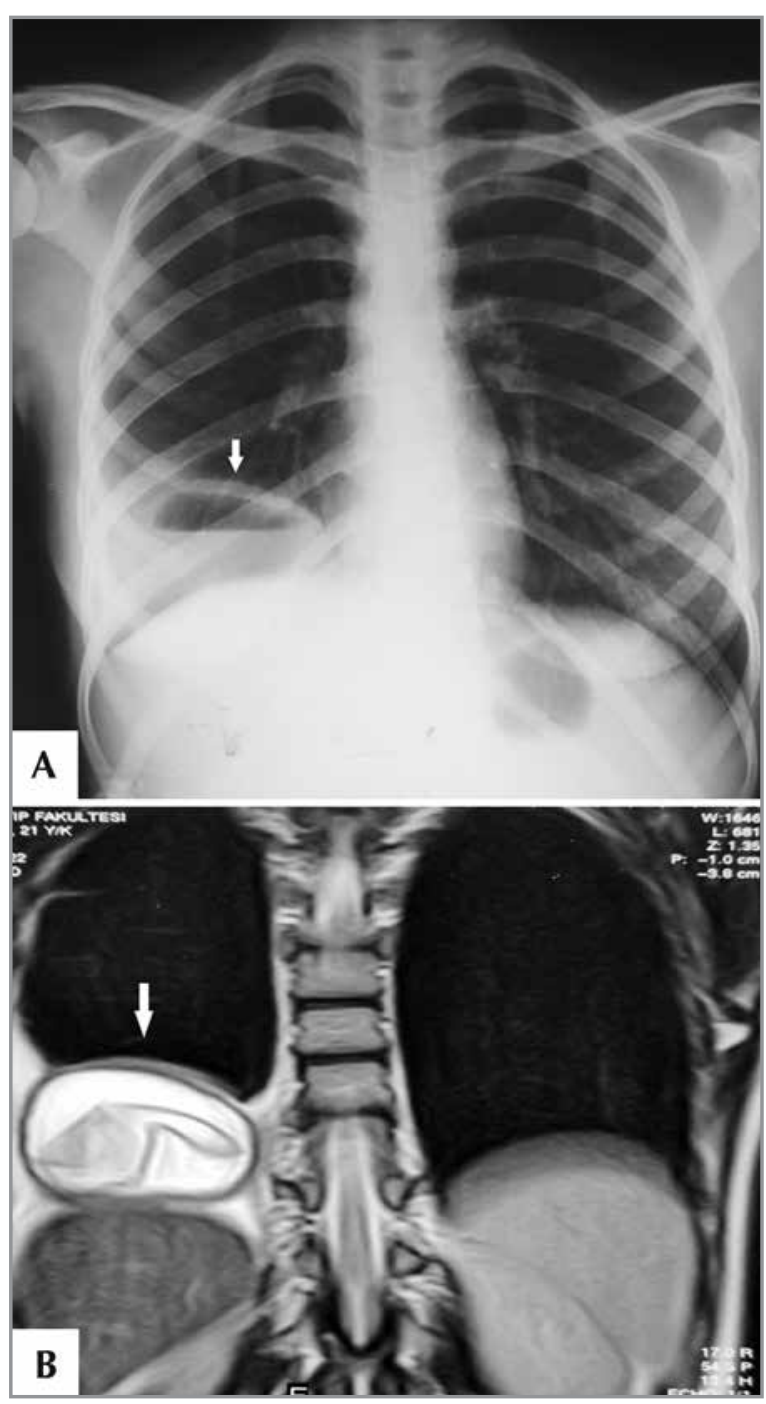

Resim 12. Plevral boşlukta perfore hidatik kist, (A) PA radyografide sağda alt zonda hava-sıvı seviyesi bulunan plevral efüzyon, (B) T2 ağırııkı koronal MR görüntülemede plevral boşlukta Sıvı ile beraber kist içinde perikistten ayrılan germinatif membranlar görülmektedir (ok). 
Plevranın hidatik kistle tutulumu sıklıkla akciğerdeki veya karaciğerdeki kistik lezyonun plevral boşluğa perfore olmasından sonra ve diğer organlardan hematojen yayılıma bağlı olarak veya agresif cerrahi girişiminden sonra meydana gelmektedir [sekonder plevral hidatidozis-(SPH)] $(39,40)$. Ayrıca radyografide tek taraflı hemitoraksta homojen yoğunluk artışı gösteren olgularda tanı amacıyla yapılan torasentezden veya perkütan trastorasik biyopsiden sonra plevral boşluktaki kistin perfore olması sonucunda da SPH meydana gelebilir $(41,42)$. Akciğerde lokalize hidatik kistin plevral boşluğa perfore olması ile yaşamı tehdit eden pnömotoraks, hidropnömotoraks, plevral efüzyon ve ampiyem gibi komplikasyonlara neden olmaktadır. Hidatik kiste bağlı pnömotoraks görülme oranı 145 olgu içeren bir çalışmada 43 (\%29.7) olgu ve 67 olgu içeren diğer çalışmada 33 $(\% 49.3)$ olgu olarak belirtilmektedir $(43,44)$. Hidatik kistle infekte olgularda karaciğerde lokalize kistik lezyonlara bağlı olarak diyafragma yoluyla plevra ve akciğer parankim tutulum oranı \%0.6-6 arasında değişmektedir (45). Bu olgularda PA radyografinin tanısal değeri yeterli değildir. USG sadece karaciğerdeki kistik lezyonları göstermektedir. MRG aynı anda plevra ve karaciğerdeki hidatik kiste bağlı tutulumla birlikte diyafragma yoluyla plevra tutulumunu daha ayrıntılı göstermektedir $(45,46)$.

\section{PLEVRA TÜMÖRLERI}

\section{Lipom}

Pevranın en sık görülen benign tümörüdür. Akciğer radyografisinde ve $\mathrm{BT}^{\prime}$ de tesadüfen görülmektedir. Yağ dansitesinde homojen atenuasyon $(-50 \mathrm{HU},-150$ HU) gösteren olgularda BT ile kesin tanı koymak mümkündür. Tümör heterojen olduğu zaman ve -150 HU'den büyük atenuasyon değeri göstermesi halinde liposarkomdan şüphe edilmelidir (47-49).

\section{Lokalize Fibröz Tümör (Benign Fibröz Mezotelyoma)}

Asbest teması ile ilişkisi belirlenmemiştir. Benign tümör olup, malign olgular da tanımlanmışır $(1,47,48)$. Tümör olguların \%80'inde visseral plevradan, \%20'si pariyetal plevradan, diyafragmatik plevradan ve mediastinal plevradan kaynaklanmaktadır (Resim 13) (50). Patognomonik radyolojik bulgular yoktur. Radyografide akciğer periferinde veya fissürde lokalize sınırları muntazam, lobule konturlu tek kitle şeklinde görülmektedir. Sıklıkla bir sap ile (\%30-50) plevraya yerleşmiştir. Kitlede kalsifikasyon ve basıya bağlı atelektazi görülebilir. BT bulguları da spesifik olmayıp, radyografi bulgularına benzemektedir (47).

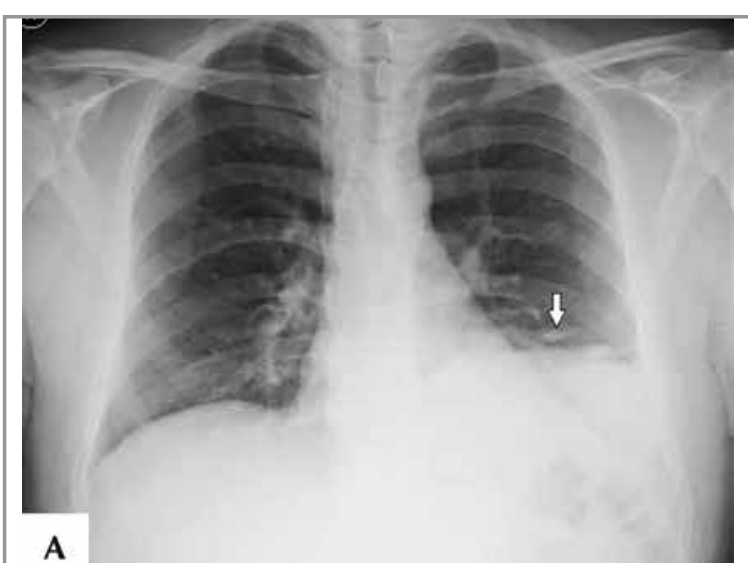

A
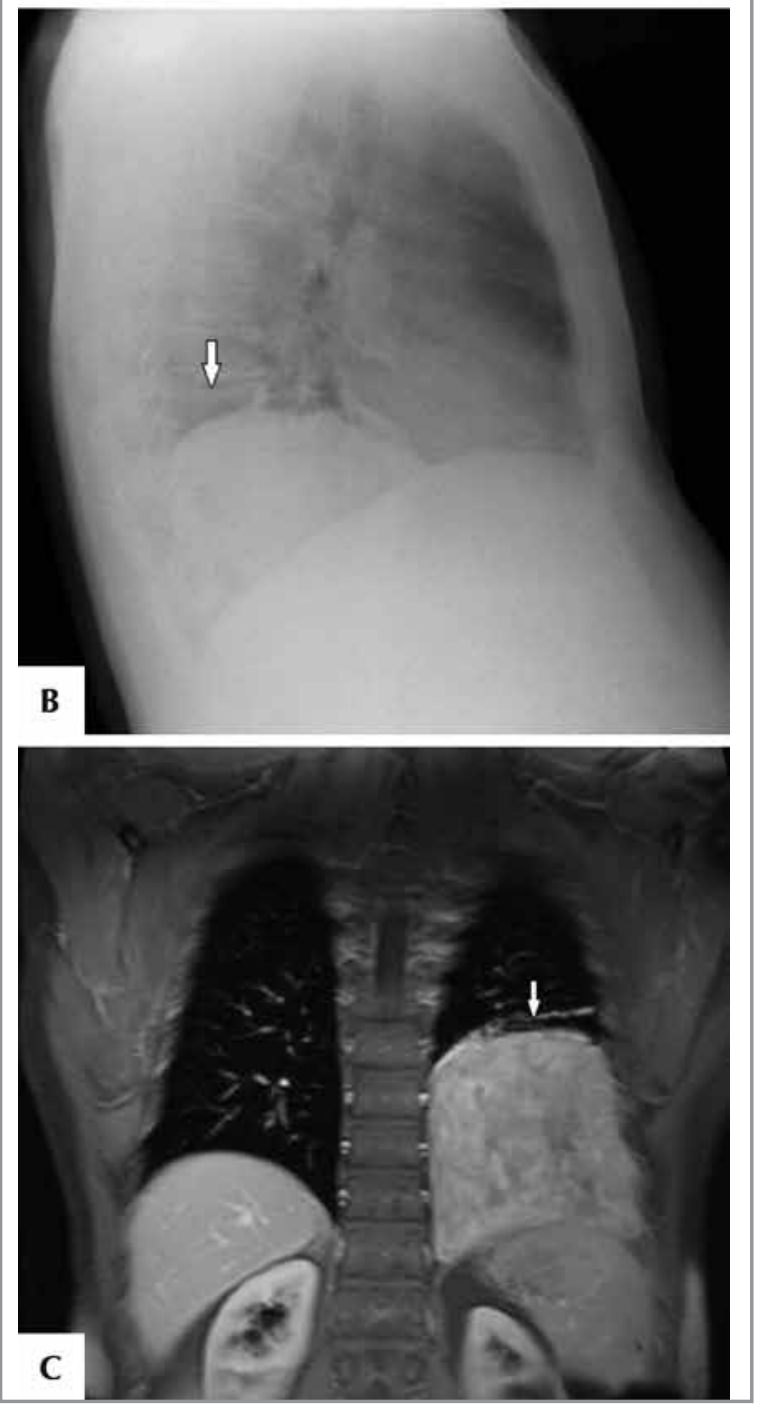

Resim 13. Lokalize fibröz tümör, (A) PA ve (B) Sol lateral radyografide kalbin sol kenarını maskelemeyen alt lob alanında lokalize kitle (ok). (C) Kontrastlı koronal T1 ağırlıklı MR görüntülemede sol diyafragmatik plevral kaynaklı yoğun kontrast tutulumu gösteren kitle (ok). 


\section{Difüz Malign Plevral Mezotelyoma}

Difüz malign plevral mezotelyoma (DMPM) etyolojisinde en önemli neden asbest veya erionit tipi mineral lif teması sorumlu tutulmaktadır. Bu liflerin inhale edilmesi ile sıklıkla plevra, daha az oranda periton ve perikard mezotelyumundan DMPM gelişmektedir. DMPM mesleksel temasta ilk temastan sonra genellikle 30-40 yıl sonra ortaya çıkmaktadır. Yani latent periyod 30-40 yıl civarındadır (51-53). Çevresel temasta ise bu değerler değişmektedir. Asbest veya erionitle temas kırsal alanda doğumla başlamaktadır. Ülkemizdeki serilerde latent periyod 50-55 yaş civarındadır. İnhale edilen asbest lifleri aerodinamik yapıları nedeniyle bronşial alanda kolayca ilerleyerek akciğerin periferik bölgelerine ulaşabilir. Akciğerlerde lenfatik dokusuna giren lifler pariyetal plevraya ulaşabilir. Diğer malign patolojilerde olduğu gibi lenfojen, hematojen yayılım yapabilir. Klinik değerlendirmede en sık bulgu nefes darlığı, plöretik olmayan yan ağrısı ve öksürüktür (53).
Akciğer radyografisinde olguların \%80-95'inde görülen orta derecedeki veya masif plevral sıvıya bağlı tek taraflı homojen yoğunluk artışı ile birlikte mediastende karşı tarafa doğru yer değiştirme görülebilir (Resim 14). Olguların \%10-29'unda plevral sıvı yoktur veya daha az oranda görülebilir. Plevral sıvı tek taraflı veya iki taraflı $(\% 5-10)$ olabilir $(54,55)$. Bazı kaynaklarda (olguların \%95'inde) mediastende yer değişikliği ile birlikte veya yer değişikliği olmaksızın tek taraflı plevral sıvı görülebileceği belirtilmiştir. Mediastende yer değişikliğinin olmaması akciğeri çevreleyen plevral kitle nedeniyle mediastenin fikse olmasından kaynaklandığı belirtilmiştir $(53,54,56,57)$. Asbest temaslı olgularda görülen plevral efüzyon DMPM'yi düşündürmesine rağmen, DMPM'nin erken döneminde görülen efüzyon kalp yetmezliğinde, ampiyemde ve diğer benign ve malign hastalıklarda görülen plevral sıvılara benzerlik göstermektedir (55). Plevral sıvı ile beraber veya sıvı olmadan nodüler veya düzensiz difüz plevral kalınlaşma en yaygın radyografi bulgusudur (Resim 14) $(58,59)$. DMPM'li

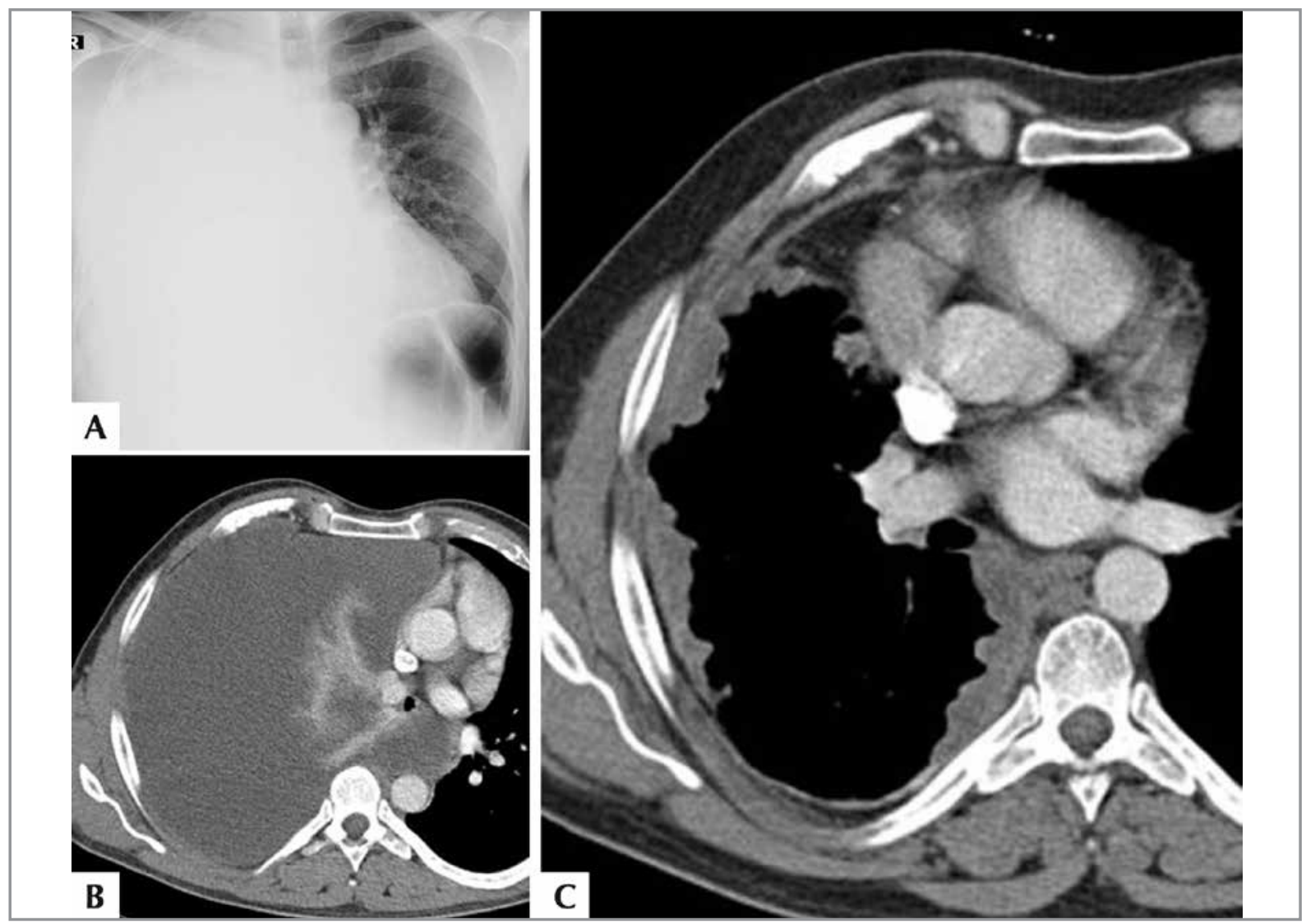

Resim 14. Difüz malign plevral mezotelyoma (A) PA radyografide sağ hemitoraksda homojen yoğunluk artışı, (B) BT'de sağda masif plevral efüzyon, kompresyon atelektazisi ve mediastende sola itinme, (C) Tedaviden sonraki takip BT'de sağ hemitoraksda plevrada düzensiz nodüler kalınlaşmalar. 
olguların \%45-60'ında plevral aralığı ve fissürleri invaze eden düzensiz konturlu veya lobüle konturlu nodüler plevra kalınlaşması veya kitle görünümü vardır. Plevral kitlenin büyümesi ve akciğeri çepeçevre sarması ile tek taraflı hacim kaybı, interkostal aralıklarda daralma ve mediastenle aynı tarafa doğru yer değişikliği görülebilir (60-62). Ancak DMPM'nin erken dönem tanısında radyografinin özgüllüğü düşüktür $(59,61)$. Plevrada difüz nodüler veya düzensiz kalınlaşma gösteren olguların ayırıcı tanısında fibrotoraksa neden olan benign hastalıklar (organize kanama, tüberküloz plörezi, ampiyem ve benign asbestoza bağlı plevral sıvı ve plevral plaklar), lokalize fibroz tümör, malign plevral mezotelyoma ve metastatik tümörler düşünülmelidir (58).

\section{Plevranın Metastatik Tümörleri}

Plevrada lokalize tömoral lezyonların önemli bölümünü diğer organlardaki tümörlerden kaynaklanan metastatik lezyonlar oluşturmaktadır. Başlıca metastatik lezyonlar akciğer kanserine (\%40), meme kanserine (\%20), lenfomaya (\%10) ve diğer organ tümörlerine bağlıdır $(48,63)$. İnvaziv timomanın plevral metastazlarını malign mezotelyomadan ayırt etmek güçtür. Metastatik plevral lezyonlar plevrada nodüler lezyonlara veya difüz kalınlaşmaya neden olmakta ve radyografik bulguları mezotelyoma ile benzerlik göstermektedir (Resim 15) (47).

\section{Postoperatif Dönemde Plevral Boşluk}

Torasik cerrahi girişim sonrası toraks duvarını oluşturan yumuşak dokular, kemik yapılar ve mediastende yer alan organlarda (özefagus, trakea ve ana bronşlar, damarlar ve kalp boşlukları), diyafragmada ve akciğer parankimindeki morfolojik değişikliklerle birlikte gelişen komplikasyonların değerlendirilmesinde akciğer radyografisi ile birlikte USG ve kontrastlı BT yaygın olarak kullanılmaktadır (64). Akciğer patolojilerinde pnömonektomi (intraplevral, ekstraplevral, intraperikardiyal ve sleeve pnömonektomi), lobektomi ve sınırI r rezeksiyon (sleeve lobektomi, segmentektomi ve parenkim koruyucu cerrahi girişim) gibi cerrahi işlemler uygulanmaktadır. Akciğer parenkiminde rezeksiyon işleminin yapılmasından sonra, rezeksiyonun tipine ve cerrahi girişimin yapılmasından sonraki geçen zamana göre değişen komplikasyonlar görülmektedir. Pnömonektomiden sonra yaklaşık 6-8 ay sonra plevral boşluk fibroz doku ile oblitere olmaktadır. Cerrahi girişimden sonra erken dönemde en yaygın görülen komplikasyonlar; hemotoraks, şilotoraks, akciğer ödemi, akciğer torsiyonu, atelektazi, pnömoni, kalıcı hava kaçağı, bronkoplevral fistül (BPF) ve ampiyemdir (64). Geç dönemde görülen komplikasyonlar; postpnömonektomi sendromu, rezeksiyon alanında nüks tümör gelişmesi, özefago-plevral fistül (\%0.2-

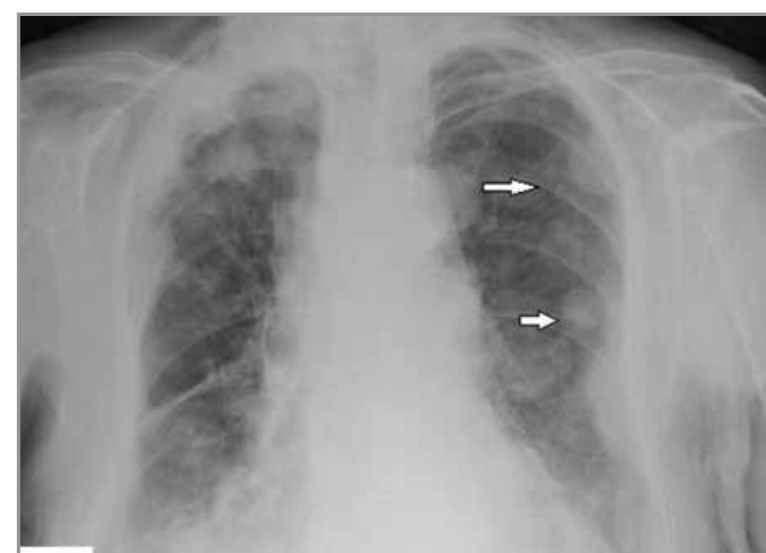

A

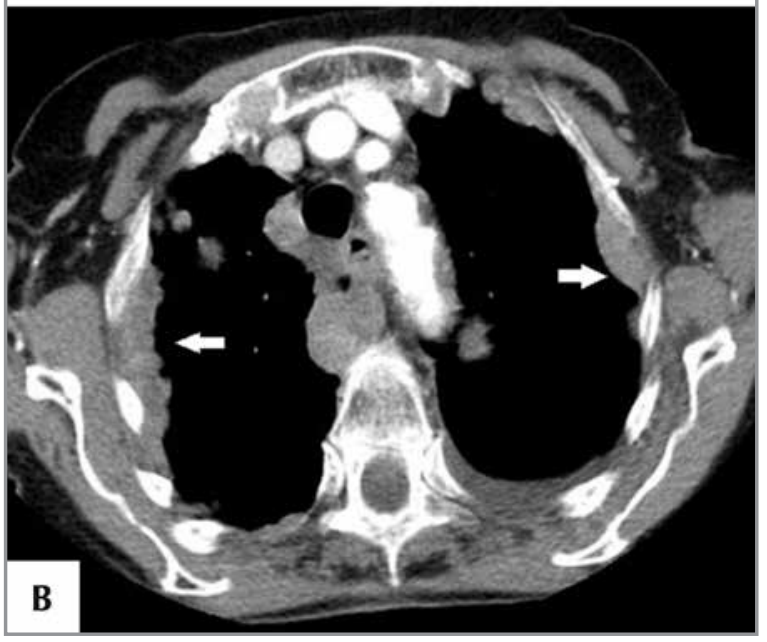

Resim 15. Meme kanserine bağlı plevral metastazlar. (A) PA radyografide iki taralı göğüs duvarında düzensiz kenarlı nodüler lezyonlar (oklar). (B) BT'de iki taraflı gögüs duvarında ve mediastinal plevrada nodüller ve kalınlaşmalar (oklar).

1.0), lobektomiden sonra hava yollarında ve damarlarda darlık ve rezeksiyon alanında yabancı cisim ve torsiyonla birlikte kardiyak herniasyondur (63). Pnömonektomiden sonra görülen en önemli komplikasyon BPF'dir. Prevalansı \%2-13 ve mortalite oranı \%30-70'dir (63)).

BPF yalnız cerrahi rezeksiyondan sonra değil, travma, infeksiyon, tümoral kitle ve radyasyon gibi nedenlerden dolayı da görülebilir $(18,33)$. BPF'de radyolojik bulgular (Resim 16):

a. Plevral boşlukta hava artışı,

b. Hava-sıvı seviyesi,

c. Hava-sıvı seviyesinde değişiklik görülmesi,

d. Tansiyon pnömotoraks,

e. Mediastenin cerrahi girişimden önceki konumuna dönmesi,

f. Aspirasyon pnömonisi bulguları $(18,33,64)$. 


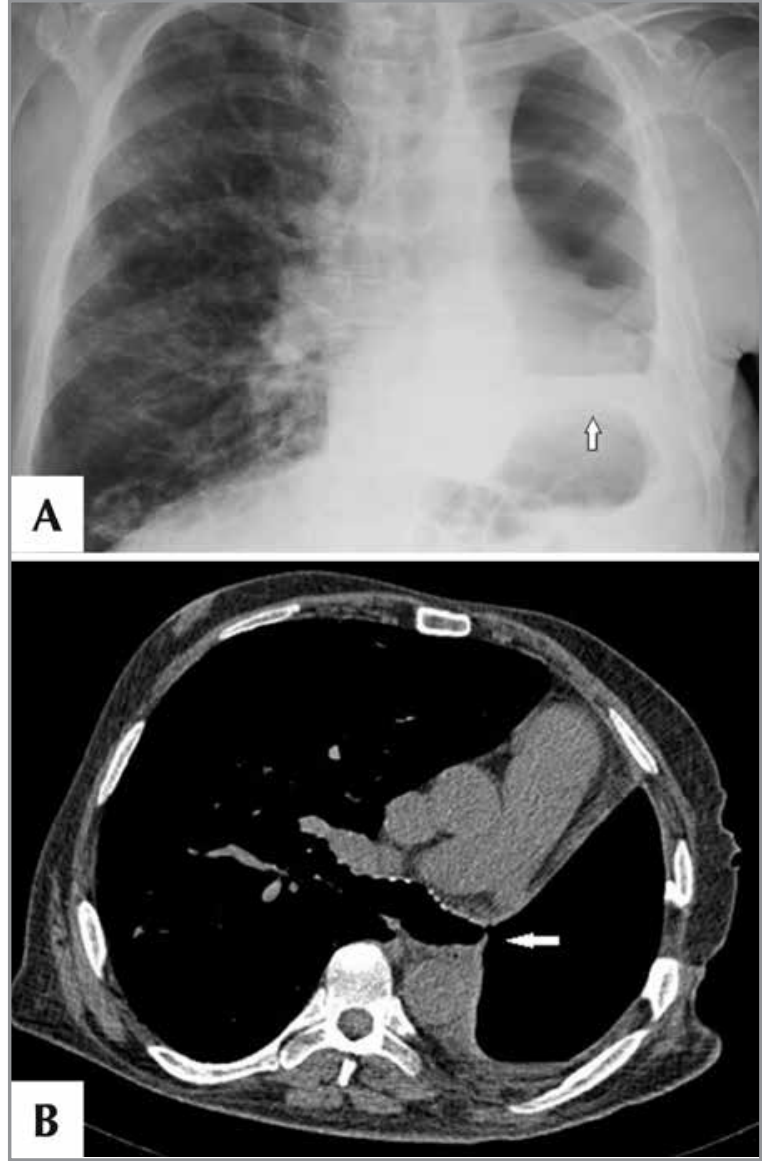

Resim 16. Pnömonektomi sonrası bronkoplevral fistül. (A) PA radyografide solda pnömonektomi sonrası radyolüsent görünüm ve hava-sıvı seviyesi görülmektedir. (ok). (B) BT'de sol ana bronş güdüğünden plevral boşluğa hava kaçağı (ok) görülmektedir.

\section{SONUÇ}

Plevra kaynaklı patolojilerin değerlendirilmesinde standart invaziv olmayan tanı yöntemi PA akciğer radyografisidir. Ancak difüz plevral lezyonların tanısında PA akciğer radyografisinin duyarlılığı ve özgüllüğü düşüktür. Toraks USG az miktardaki veya loküle plevral sıvının saptanmasında yararlı yöntemdir. USG plevral sıvıların morfolojik yapısını radyografiye göre daha ayrıntılı göstermektedir. Ayrıca USG rehberliğinde plevra biyopsisi ve sıvı drenajının güvenilir şekilde yapılması mümkündür. Kalsifikasyon gibi radyografide saptanan plevral lezyonlar, plevral lezyonların periferik parankimal lezyonlardan ayırt edilmesi BT de daha ayrıntılı olarak gösterilmektedir. Ancak kesin tanı için görüntüleme bulguları ile birlikte klinik bulguların kombine edilmesi gerekmektedir. Kontrastlı toraks BT yapılamıyan ve diğer yöntemlerle tanı konulamayan olgularda MRG tamamlayıcı yöntem olarak kullanılmaktadır.

\section{KAYNAKLAR}

1. Müller NL. Imaging of the plevra. Radiology 1993:297-309.

2. Metintaş M. Plevra hastalıkları. TTD 9. Göğüs Hastalıkları Mesleki Gelişim Kursu. Antalya: 2012:116-23.

3. Sarısoy HT, Gürcan Mi, Demirci A. Plevra patolojilerinde radyolojik görüntüleme. I Clin Analitical Med 2010;11-5.

4. Vix VA. Roentgenographic manifestations of pleural disease. Semin Roentgenol 1977;12:277-86.

5. Light RW. Pleural disease. 4th ed. Philadelphia: Lippincott Williams \& Wilkins, 2001:21-41.

6. Akman C. Radyolojik değerlendirme. In: Gözü O, Köktürk O (editörler). Plevral hastalıkları. Toraks Kitapları 2003:31-9.

7. Rubens MB, Padley SP. Pleura. In: Sutton D (ed). Text book of radiology and imaging. $6^{\text {th }}$ ed. Edinburg: Churchill Livingstone, 1998:579-97.

8. Lipscomb DY, Flower CDR, Hadfield JW. Ultrasound of the pleura: an assessment of its clinical value. Clin Radiol 1981;32:289-90.

9. Moskowitz H, Platt RI, Schatter R, Mellins H. Roentgen visualization of minute pleural effusion. An experimental study to determine the minimum amount of pleural fluid visible on a radiograph. Radiology 1973;109:33-5.

10. Kocijancic I, Vidmar K, Ivanovi- Herceg Z. Chest sonography versus lateral decubitus radiography in the diagnosis of small pleural effusions. I Clin Ultrasound 2002;31:69-74.

11. Fleischner FG. Atypical arragement of free pleural effusion. Radiol Clin North Am 1963; 1:347-62.

12. Higgins JA, Juergens IL, Bruwer AJ, Parkin TW. Loculated interlobar pleural effusion due to congestive heart failure; report of five cases. Arch Intero Med 1955;96:180-7.

13. Emamian SA, Kaasbol MA, Olsen JF, Pedersen JF. Accuracy of the diagnosis of pleural effusion on supine chest X-ray. Eur Radiol 1997;7:57-60.

14. Ruskin JA, Gurrey JW, Thorsen MK, Goodman LR. Detection of pleural effusions on supine chest radiographs. AJR Am J Roentgenol 1987; 148:681-3.

15. Woodring $J H$. Recognition of pleural effusion on supine radiographs; how much fluid is required? AIR Am J Roentgenol 1984;142:59-64.

16. Kitazono MT, Lau CT, Parada AN, Renjen P, Miller WT Jr. Differentiation of pleural effusions, from accuracy of bedside chest radiography. AJR Am J Roentgenol 2010;194:407-12.

17. Özkan R. Plevra hastalıklarda radyolojik bulgular. Türkiye Klinikleri J Radiol Special Topics 2002;2:96-110.

18. Müller NL, Fraser RS, Colman NC, Pare PD. RadiollogiC diagnosis of disease of the chest. $1^{\text {st }}$ ed. Philadelphia: WB Saunders Com, 2001:664-5.

19. Savaş I. Pleural fibrosis. In: Gözü O, Köktürk O (editörler) Plevra hastalıkları. Toraks Kitapları 2003:322-4.

20. Metintaş M, Hillerdal G, Metintaş S. Environmental asbestos exposure and malignant plevral mesothelioma. Respir Med 1999;93:349-55.

21. Metintaş M. Asbest temasına bağlı pleural patolojiler ve mezotelyoma. Türkiye Klinikleri I Int Med Sci 2005;1:96-110.

22. Çöplü L. Aspeste bağlı plevra hastalıkları. In: Gözü O, Köktürk O (editörler). Plevra hastalıkları. Toraks Kitapları 2003:4:224-9.

23. McLoud TC. Conventional radiography in the diagnosis of asbestos-related disease. Radiol Clin North Am 1992;30:1177-89. 
24. Hillerdal G, Lindgren A. Pleural plaques; Correlation of autopsy findings to radiographic findings and occupational history. Eur J Respir 1980;61:314-9.

25. Mc Loud TC. Pleura. In Thoracic radiology. The requisite Chapter 18. St Louis: Mosby, 1998;483-96.

26. Mc Adams Hr, Erasmus J, Winter JA. Radiologic manifestations of pulmonary tuberculosis. Radiol Clin North Am 1995;33:655-78

27. Lillingtone GA. A diagnostic approach to chest. $3^{\text {rd }}$ ed. Baltiomore: Williams \& Wilkins, 1987:369-437.

28. Topcu S. Pnömotoraks. In: Gözü O, Köktürk O (editörler). Plevra hastalıkları. Toraks Kitapları 2003;4:302-21.

29. Cobbel WG, Rhea WG, Nelson IA, Daniel RA. Spontaneous pneumothorax. J Thorac Cardiovasc Surg 1963;46:331-45.

30. Altınnok T, Topcu S. Pneumotoraks. In: Özlü T, Metintaş U, Karadağ M, Kaya A (editörler). Solunum sistemi ve hastalıkları. İstanbul: Istanbul Tıp Kitabevi 2010;1997-2003.

31. Miller LA, Chest Wall. Lung and pleural space travma. Radiol Clin North Am 2006;44:213-24.

32. Tocino IM, Miller MH, Fairfax WR. Distrubation of pneumothorax in the supine and semi recumbent critically ill adult. AJR Am / Roentgenol 1985;144:901-5.

33. Wilson AG. Pleura and pleural disorders. In : Armstrong $P$, Wilson AG, Dee P, Hansell DM (eds). Imaging of the disease of the chest. $2^{\text {nd }}$ ed. St Louis: Mosby, 1995:641-716.

34. Ravdin II. Entamoeba histolytica. In: Mandell GL, Bennet JE, Dolin $R$ (eds). Principles and practice of infectious disease. $2^{\text {nd }}$ ed. Philadelphia: Churchill Livingstone, 1998:2798-810.

35. Stephan SJ, Urogoda CG. Pleuro pulmonary amebiasis: a rewiev of 40 cases. Br J Dis Chest 1970;64:96-108.

36. Skerett SI, Plorde JJ. Parasitic infections of the pleural space. Semin Respir Med 1982;13:242-58.

37. Emlik D, Kiresi D, Sunam GS, Kivrak AS, Ceran S, Odev K. Intrathoracic extrapulmonary hydatid disease: radiologic manifestations. Can Assoc Radiol I 2010;61:170-6.

38. Ödev K, Kaya HE. Akciğer ve toraks hidatik kistinde radyolojik bulgular. Türkiye Klinikleri J Radiol Special Topics 2015;8:21-33.

39. Roberts PP. Parazitic infections of the pleural space. Semin Respir Infect 1988;3:362-82.

40. Aguilar X, Fernandez- Muixi J, Magarolos R, Saurí A, Vidal F, Richart C. An unusual presentation of secondary pleural hydatidosis. Eur Respir J 1998;11:243-5.

41. Al Karawi MA, El Shiekh AR, El Tayeb BO, Yasawy MI. Un intentional percutaneous aspiration of a pleural hydatid cyst. Thorax 1991;46:859-60.

42. Kıreşi DA, Karabacakoğlu A, Ödev K, Karaköse S. Uncomman locations of hydatid cysts. Acta Radiol 2003;44:622-36.

43. Arıbaş OK, Kanat F, Görmüş N, Turk E. Pleural complications of hydatid disease. J Thorac Cardiovasc Surg 2002; 123:492-7.

44. Kuzucu A, Soysal Ö, Özgel M, Yologlu S. Compicated hydatid cysts of the lung: clinical and theropeutic Issues. Ann Thorac Surg 2004;77;1200-4.

45. Pedrosa I, Saiz A, Arrazola I, Ferreirós I, Pedrosa CS. Hydatid disease: radiologic and pathologic features and complications. Radiographics 2000;20:795-817.
46. Kilani T, El Hammani S, Horchani H, Ben Miled-Mrad K Hantous S, Mestiri I, et al. Hydatid disease of the liver with thoracic involvement. World I Surg 2001;25:40-5.

47. Dynes MC, White Em, FRY WA, Ghahremani GG. Imaging manisfestations of pleural tumors. Radiographics 1992; 12:1191-201.

48. Epler GR, McLoud TC, Munn CS, Colby TV. Pleural lipoma. Diagnosis by computed tomography. Chest 1986;90:265-8.

49. Munk PL, Müller NL. Pleural liposarcoma. CT diagnosis. J Comput Assist Tomogr 1988;12:709-10.

50. Hill JK, Heitmiller RF, Askin FB, Kuhlman JE. Localized benign pleural mesothelioma arising in a radiation field. Clin Imaging 1997;21:187-94.

51. Metintas M, Ozdemir N, Hillerdal G, Uçgun I, Metintas S, Baykul C, et al. Environmental asbestos exposure and malignant pleural mesothelioma. Respir Med 1999;93:349-55.

52. Boutin C, Schlesser M, Frenay C, Astoul P. Malignant pleural mesothlioma. Eur Respir J 1998;12:972-81.

53. Metintaş M. Asbest temasına bağlı plevral patolojiler ve mezotelyoma. Türkiye Klinikleri J Int Med Sci 2005;1:96110.

54. Wechsler RJ, Steiner RM, Conant EF. Occupationally induced neoplasms of the lung and pleura. Radiol Clin North Am 1992;30:1245-68.

55. Ismail-Khan $R$, Robinson LA, Williams CC, Garrett $C R$, Bepler G, Simon GR. Malignant pleural mesothelioma. A compre hensive review. Cancer Control 2006; 13:255-63.

56. Hansell DM, Armstrong P, Lynch DA, McAdams HP. Imaging of the diseases of the chest. 4th ed. Philadelphia: Elsevier Mosby, 2005:859-63.

57. McLoud TC. CT and MR in pleural disease. Clin Chest Med 1998;19:261-76.

58. Ödev K, Metintaş M, Özkan R. Malign plevral mezotelyoma. Türkiye Standartları Rehberi. Radyolojik Görüntüleme Bulguları. Eskişehir: OGÜ, 2014;43-53.

59. Marom EM, Erasmus J/, Pass HI, Patz EF Jr. The role of imaging in malignant pleural mesothelioma. Semin Oncol 2002;29:26-35.

60. Eibel $R$, Tuengerthal $S$, Schoenberg SO. The role of new imaging techniques in diagnosis and staging of malignant pleural mesothelioma. Curr Opin Oncol 2003;15:131-8.

61. Rabinowitz JG, Efremidis SC, Cohen B, Dan S, Efremidis $A$, Chahinian AP, et al. A comparative study of mesothelioma and asbestosis using computed tomography and conventional chest radiography. Radiology 1982;144:453-60.

62. Henschke Cl, Yankelevitz DF, Davis SD. Pleural disease: multimodality imaging and clinical management. Curr Probl Diagn Radiol 1991;20:159-79.

63. Kim EA, Lee KS, Shim YM, Kim J, Kim K, Kim TS, et al. Radiographic and CT findings in complications following pulmonary resection. Radiographics 2002;22:67-86.

64. Sarısoy HT. Postoperatif dönem hastalarında radyolojik görüntüleme. Toraks Cerrahi Bülteni 2013;202-6. 